\title{
Microstructural Evolution of Reaction Layer of 1.5 GPa Boron Steel Hot-Dipped in $\mathrm{Al}-7 \mathrm{wt} \% \mathrm{Ni}-6 \mathrm{wt} \% \mathrm{Si}$ Alloy
}

\author{
Jeong-Yong Lee, Hoejun Heo, Namhyun Kang * ${ }^{\mathbb{D}}$ and Chung-Yun Kang * \\ Department of Materials Science and Engineering, Pusan National University (PNU), Pusan 46241, Korea; \\ jy689654@gmail.com (J.-Y.L.); hjheo@pusan.ac.kr (H.H.) \\ * Correspondence: nhkang@pusan.ac.kr (N.K.); kangcy@pusan.ac.kr (C.-Y.K.); \\ Tel.: +82-51-510-3274 (N.K.); +82-10-8329-8429 (C.-Y.K.)
}

Received: 13 November 2018; Accepted: 13 December 2018; Published: 15 December 2018

\begin{abstract}
The constituents, distribution, and characteristics of the phases formed on the coating layer of boron steel hot-dipped in Al-7wt $\% \mathrm{Ni}-6 \mathrm{wt} \% \mathrm{Si}$ were evaluated in detail. In particular, the microstructure and phase constitution of the reaction layer were characterized. Moreover, the microstructural evolution mechanism of the phase was presented with reference to the (Al-7wt $\% \mathrm{Ni}-6 \mathrm{wt} \% \mathrm{Si}$ )-xFe from the pseudo-binary phase diagram. The solidification layer consisted mainly of $\mathrm{Al}, \mathrm{Al}_{3} \mathrm{Ni}$, and $\mathrm{Si}$ phases. Reaction layers were formed in the order of $\mathrm{Al}_{9} \mathrm{FeNi}(\mathrm{T}), \mathrm{Fe}_{4} \mathrm{Al}_{13}(\theta)$, and $\mathrm{Fe}_{2} \mathrm{Al}_{5}(\eta)$ from the solidification layer side. In addition, the $\mathrm{k}\left(\mathrm{Fe}_{3} \mathrm{AlC}\right)$ layer was formed at the $\mathrm{Fe}_{2} \mathrm{Al}_{5}(\eta) /$ steel interface. From pseudo-binary phase diagram analysis, it was found that $\mathrm{Fe}_{4} \mathrm{Al}_{13}(\theta)$ can form when the Fe concentration is over $2.63 \mathrm{wt} \%$ in the $690{ }^{\circ} \mathrm{C} \mathrm{Al-7wt} \% \mathrm{Ni}-6 \mathrm{wt} \% \mathrm{Si}$ molten metal. When the concentration of Fe increased to $10.0-29.0 \mathrm{wt} \%$, isothermal solidification occurred in the $\mathrm{Fe}_{4} \mathrm{Al}_{13}(\theta)$ and $\mathrm{Al}_{9} \mathrm{FeNi}(\mathrm{T})$ phases simultaneously. Moreover, given that the $\mathrm{T}$ phase does not dissolve $\mathrm{Si}$, it was discharged, and the $\mathrm{Si}$ phase was formed around the $\mathrm{Al}_{9} \mathrm{FeNi}(\mathrm{T})$ phase. The $\mathrm{Fe}_{2} \mathrm{Al}_{5}(\eta)$ phase was formed by a diffusion reaction between $\mathrm{Fe}_{4} \mathrm{Al}_{13}(\theta)$ and steel, not a dissolution reaction. Moreover, $\mathrm{Al}_{2} \mathrm{Fe}_{3} \mathrm{Si}_{3}\left(\tau_{1}\right)$ was formed at the $\mathrm{Fe}_{4} \mathrm{Al}_{13}(\theta)-\mathrm{Fe}_{2} \mathrm{Al}_{5}(\eta)$ interface by discharging $\mathrm{Si}$ from $\mathrm{Fe}_{4} \mathrm{Al}_{13}(\theta)$ without $\mathrm{Si}$ solubility. Furthermore, the $\mathrm{Fe}_{3} \mathrm{AlC}(\mathrm{K})$ layer was formed by carbon accumulation that discharged in the $\mathrm{Fe}_{2} \mathrm{Al}_{5}(\eta)$ region transformed from steel to $\mathrm{Fe}_{2} \mathrm{Al}_{5}(\eta)$. The twin regions in the $\mathrm{Fe}_{4} \mathrm{Al}_{13}(\theta)$ and $\mathrm{Fe}_{2} \mathrm{Al}_{5}(\eta)$ grain were due to the strains caused by the lattice transformation in the constrained state, wherein the phases are present between the $\mathrm{Al}_{9} \mathrm{FeNi}(\mathrm{T})$ layer and steel.
\end{abstract}

Keywords: hot-dipping; intermetallics formation; diffusion; phase transformation

\section{Introduction}

In recent years, the automobile industry has been using boron steel, in which boron is added to a low alloy steel, for environmental friendliness, low fuel consumption, and low weight. When boron is added to steel, the boron is segregated in the previous austenite grain boundaries, even if only approximately $20 \mathrm{ppm}$ is added, and the hardenability can be significantly improved by delaying the ferrite nucleation on cooling. Moreover, boron steel is boron-added low alloy steel, and it is a type of advanced high-strength steel (AHSS) with a tensile strength of 1.5 GPa [1]. Due to the high strength of boron steel, cold forming is difficult, and the spring-back phenomenon occurs after forming. Therefore, hot stamping is performed to maintain the ductility by heating to a temperature of A3 or higher, press forming, and rapid cooling to maintain a high strength. Hot stamping involves heating at a temperature of $\mathrm{A} 3$ or higher, to ensure ductility, and then quenching to maintain a high strength [2-5]. In hot stamping, surface oxidation and surface decarburization occur on heating at a high temperature; 
therefore, it is mainly performed with $\mathrm{Al}-10 \% \mathrm{Si}$ coating, which has an excellent oxidation resistance at high temperatures [6-8]. When the Al-Si hot-dipped boron steel was laser-welded, $\mathrm{Al}$ and $\mathrm{Si}$ segregation portions were formed in the fusion zone. The portion formed a ferrite with low hardness during hot stamping, and it was reported that the tensile properties of the fusion zone decreased [9-12]. In addition, Yoon et al. reported that a hook-shaped $\mathrm{Fe}_{3}$ ( $\mathrm{Al}, \mathrm{Si}$ ) intermetallic compound was formed on the interface between the fusion zone and base metal during laser welding. Moreover, it was transformed to polygonal ferrite during the hot stamping processes, and the tensile properties were degraded [13].

There are several studies on the development of coating compositions for the inhibition of ferrite formation in Al-Si hot-dipped boron steel welding. Coating compositions were designed by adding $\mathrm{Mn}$ or $\mathrm{Ni}$, which are austenite-forming elements, to Al. In general, research on the microstructures of $\mathrm{Al}-7 \mathrm{wt} \% \mathrm{Mn}$ [14] and the $\mathrm{Al}-7 \mathrm{wt} \% \mathrm{Ni}$ [15] coating layer was conducted. In the abovementioned studies, the desired Ni phase $\left(\mathrm{Al}{ }_{9} \mathrm{FeNi}\right)$ and $\mathrm{Mn}$ phase $\left(\mathrm{Al}_{6} \mathrm{Mn}, \mathrm{Al}_{11} \mathrm{Mn}_{4}\right)$ were formed; however, the $\mathrm{Fe}_{2} \mathrm{Al}_{5}(\mathrm{\eta})$ phase layer, which is the cause of ferrite formation, was formed with a thickness of approximately $100 \mu \mathrm{m}$.

On the other hand, when $\mathrm{Si}$ is added to a molten bath when hot-dipping the carbon steel and low alloy steel, the thickness of the produced intermetallic compound $\mathrm{Fe}_{2} \mathrm{Al}_{5}(\eta)$ phase during plating can be reduced. In addition, the melting point and viscosity of the molten bath can be reduced to increase the coating ability [16-18]. Several mechanisms were proposed to explain the decrease in the thickness of the $\mathrm{Fe}_{2} \mathrm{Al}_{5}(\eta)$ phase due to the addition of $\mathrm{Si}$, such as an $\mathrm{Al}$ diffusion delay due to the Si solubility in the $\mathrm{Fe}_{2} \mathrm{Al}_{5}(\eta)$ phase vacancy [16,19], Al diffusion delay due to the Si segregated in the $\mathrm{Fe}_{2} \mathrm{Al} 5(\eta)$ phase grain boundary [20], and a reduction in the $\mathrm{Al}$ activation coefficient due to the addition of Si [21,22]. In most studies, it was reported that $\mathrm{Si}$ inhibits the growth of the $\mathrm{Fe}_{2} \mathrm{Al}_{5}(\eta)$ phase by reducing the diffusion and activation coefficients of Al. On the other hand, Lemmens B. et al. reported that the amount and thickness of the Al-Fe-Si ternary phase $\left(\tau_{1}, \tau_{5}\right)$ generated in the $\mathrm{Fe}_{2} \mathrm{Al}_{5}(\eta)$ phase increased and the thickness of the $\mathrm{Fe}_{2} \mathrm{Al}_{5}(\eta)$ phase decreased when the amount of $\mathrm{Si}$ added to the coating bath was increased [23].

Yun et al. reported that the thickness of the $\mathrm{Fe}_{2} \mathrm{Al}_{5}(\eta)$ phase decreased and the amount of the $\mathrm{Al}_{9} \mathrm{FeNi}(\mathrm{T})$ phase (which they think that inhibiting ferrite formation phase when welding) increased as the amount of $\mathrm{Si}$ increased through hot-dip coating with (1-6) $\mathrm{wt}_{\mathrm{t}}^{\mathrm{oSi}} \mathrm{Sidded}$ to Al-7 $\mathrm{wt} \% \mathrm{Ni}$ [24]. In particular, it was reported that due to the addition of $\mathrm{Si}, 1-5$ at $\%$ of $\mathrm{Si}$ was dissolved in the $\eta$ phase to interfere with the growth of Al. Moreover, the $\mathrm{Al}_{2} \mathrm{Fe}_{3} \mathrm{Si}_{3}\left(\tau_{1}\right)$ phase was generated, and it preferentially consumed Al. However, there was no mention of the formation of a reaction layer during the coating, the characteristics, and formation mechanism of the reaction phases.

Given that the $\mathrm{Fe} 2 \mathrm{Al} 5(\eta)$ phase of the reaction layer that contains a minimum of $5 \mathrm{wt} \%$ of $\mathrm{Si}$ during the hot-dip coating of the $\mathrm{Al}$ alloy is $2 \mu \mathrm{m}$ or lower in thickness, and the grain diameter of the Al-Fe-Si ternary phase $\left(\tau_{1}, \tau_{5}\right)$ is $1 \mu \mathrm{m}$ or lower, studies that employ transmission electron microscopy (TEM) are required. However, in most studies, only X-ray diffraction (XRD), energy-dispersive X-ray spectroscopy (EDS), and electron backscatter diffraction (EBSD) analyses were conducted; thus, the accuracy of the analyses was limited. In addition, there are no reports on the formation of carbon-related phases during the coating of steels that contain a certain amount of carbon, such as boron steel $(0.22 \mathrm{wt} \%$ of carbon).

Hence, in this study, the reaction layer formed on the boron steel coated at $690^{\circ} \mathrm{C}$ for $2 \mathrm{~min}$ in an $\mathrm{Al}-7 \mathrm{wt} \% \mathrm{Ni}-6 \mathrm{wt} \% \mathrm{Si}$ molten bath was deflected by a focused ion beam (FIB), and phase identification was conducted using TEM and TEM-EDS. Moreover, Electron Backscatter Diffraction (EBSD) was used for the microstructure analysis of the macroscopic reaction layer and solidification layer. The mechanism of formation of intermetallic compounds was further investigated using a pseudo-binary phase diagram. 


\section{Materials and Methods}

The base metal used in this study was boron steel (22MnB5) with a thickness of $1.4 \mathrm{~mm}$, for which the chemical composition is presented in Table 1 . The Al-7wt $\% \mathrm{Ni}-6 \mathrm{wt} \% \mathrm{Si}$ alloy was prepared by appropriately mixing high-purity (99.99\%) Al ingot, high-purity (99.99\%) Al-15wt\%Si ingot, and high-purity (99.99\%) Ni ingot. The specimens to be coated were cut to a size of $40 \mathrm{~mm} \times 120 \mathrm{~mm}$, pickled in a solution that consisted of $40 \mathrm{~mL}$ of $\mathrm{H}_{2} \mathrm{SO}_{4}$ and $200 \mathrm{~mL}$ of $\mathrm{CH}_{3} \mathrm{OH}$ for $5 \mathrm{~min}$, and then rinsed using $\mathrm{C}_{2} \mathrm{H}_{5} \mathrm{OH}$.

Table 1. Chemical composition ( $w \mathrm{t} \%$ ) of Boron steel.

\begin{tabular}{cccccccccc}
\hline $\mathbf{C}$ & $\mathbf{S i}$ & $\mathbf{M n}$ & $\mathbf{C r}$ & $\mathbf{N b}$ & $\mathbf{T i}$ & $\mathbf{B}$ & $\mathbf{P}$ & $\mathbf{S}$ & $\mathbf{F e}$ \\
\hline 0.2285 & 0.2383 & 1.1890 & 0.1833 & 0.0036 & 0.0363 & 0.0023 & 0.0015 & 0.0015 & Bal. \\
\hline
\end{tabular}

The prepared hot-dip coated alloy was heated in a crucible set in a high-frequency furnace, and then maintained at a coating temperature of $690{ }^{\circ} \mathrm{C}$ for melting. The pre-treated specimens were pre-heated at $150{ }^{\circ} \mathrm{C}$ for $20 \mathrm{~s}$ to remove moisture from the surface, and then placed in a molten bath of Al-7wt $\% \mathrm{Ni}-6 \mathrm{wt} \% \mathrm{Si}$, which was maintained at $690{ }^{\circ} \mathrm{C}$ for $2 \mathrm{~min}$ for coating. After coating, the specimens were cooled in air.

The coated specimens were polished in the normal direction using \#180-2500 SiC sandpaper, a $1 \mu \mathrm{m}$ diamond suspension, and a $0.04 \mu \mathrm{m}$ colloidal silica suspension. The coating layer was then etched using $49 \mathrm{~mL}$ of distilled water and $1 \mathrm{~mL}$ of HF according to ASTM B487-85. The etched coating layer was observed using an optical microscope (Olympus BX51M; Tokyo, Japan) and field-emission scanning electron microscopy (FE-SEM) system (Carl Zeiss SUPRA 45; Oberkochen, Germany). Moreover, EDS (EDAX; Mahwah, NJ, USA) and field-emission electron probe micro-analysis (FE-EPMA) (JEOL JXA-8530F; Tokyo, Japan) were performed to analyze the composition of the coating layer. For FE-EPMA, area analysis was conducted with a voltage of $10 \mathrm{kV}$, a current of $100 \mathrm{nA}$, and step sizes of $0.1-0.5 \mathrm{~mm}$ in the non-etched state.

For the phase analysis of the reaction layer, the TEM specimens were deflected using FIB (FEI, Scios; Hillsboro, OR, USA). The diffraction pattern and chemical composition were analyzed using FE-TEM (FEI, TALOS F200X; Hillsboro, OR, USA). In addition, EBSD (EDAX, Hikari; Mahwah, NJ, USA) was used for the phase distribution and crystal orientation analyses. In particular, phase distributions were confirmed by Chi-Scanning that using EDS and EBSD. The thickness and length of the reaction layer were measured using the Image-Plus Pro image analysis program. The equilibrium composition of each phase formed during the coating and the (Al-7wt\%Ni-6wt\%Si)-xFe pseudo-binary phase diagram were obtained using Thermo-Calc ${ }^{\mathrm{TM}}$ software Ver. 6.0 (Solna, Sweden), for the evaluation of the formation mechanism of each phase.

\section{Results and Discussion}

\subsection{Microstructure of Solidification Layer}

\subsubsection{Identification of Solidification Layer Phases}

Figure 1 presents the structure of the specimen coated at $690{ }^{\circ} \mathrm{C}$ for $2 \mathrm{~min}$ in an $\mathrm{Al}-7 \mathrm{wt} \% \mathrm{Ni}-6 \mathrm{wt} \%$ Si molten bath, as observed using the optical microscope. The coating layer was classified into a solidification layer (SL) and reaction layer (RL). Reaction layer (RL) is boron-steel/coating layer interface that composed of gray layers that observed some black particles inside and ivory phases that attached to gray layer and grown to solidification layer.

The second phases in the solidification layer were mainly formed on the grain (or dendrite) boundary. 


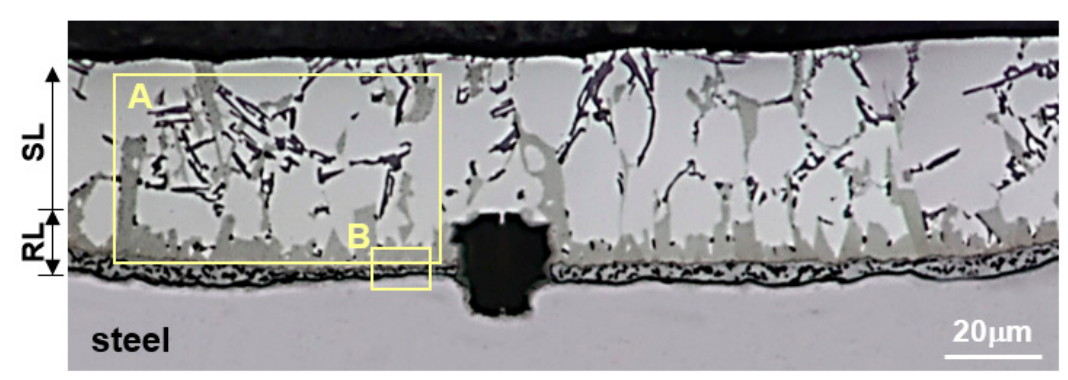

Figure 1. Optical microstructure of specimen hot-dipped at $690{ }^{\circ} \mathrm{C}$ for $2 \mathrm{~min}$.

Figure 2 presents an SEM image of the area indicated by A in Figures 1 and 3 presents the results of the EBSD analysis. Given that EBSD was conducted in a non-etched state, the microstructure distribution was slightly different from that in the SEM image by re-polishing. Table 2 presents the results of the composition analysis of the phases labeled 1-11 in Figure 2 using EDS point analysis. The black needle-shaped phases 1-3 in Figure 2 represent Si. A small amount of Al was detected; however, Si did not dissolve in Al [25]. Hence, the detected Al represents the Al matrix in the EDS analysis results. In the EBSD results, the phase was $\mathrm{Si}$, whereas the structures in the SEM image consisted of aggregates of fine grains, and the randomly shaped phases were parts of one grain. On the other hand, phases 4-11 exhibited a slight color difference when observed using an optical microscope and SEM. Moreover, phases 9-11 were reaction layer phases, as they were connected to the reaction layer. These phases were classified into two phase groups by EDS analysis. Phases 4-11 contained $\mathrm{Al}$ and $\mathrm{Ni}$ as the main components, but divided into two kinds: 4-6 in which $\mathrm{Si}$ and Fe are small in solid content and 7-11 phases in which Fe and Si contents are higher than those phases. From the EBSD results, phases $4-6$ were $\mathrm{Al}_{3} \mathrm{Ni}$ (orthorhombic). Furthermore, $\mathrm{Al}_{3} \mathrm{Ni}$ was observed as a polygonal shape in the SEM image; however, from the EBSD results, it was found to be an aggregate of very fine grains. It was confirmed that phases $7-11$ were $\mathrm{Al}_{9} \mathrm{FeNi}$ ( $\mathrm{T}$, monoclinic) phases. In Figure 2, Figures 7 and 8 , the $\mathrm{Al}_{9} \mathrm{FeNi}(\mathrm{T})$ phases were present in the solidification layer, which were similar to the phase indicated by the red circle in Figure 3. Moreover, these were mostly observed near the reaction layer.

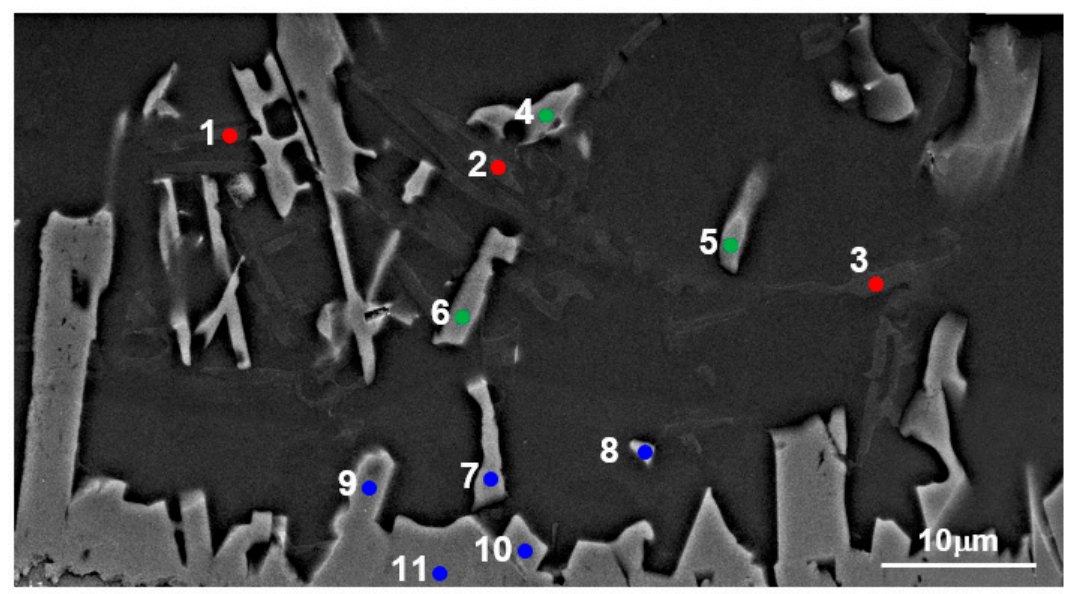

Figure 2. SEM image showing microstructure of area denoted as a rectangular "A" in Figure 1. 

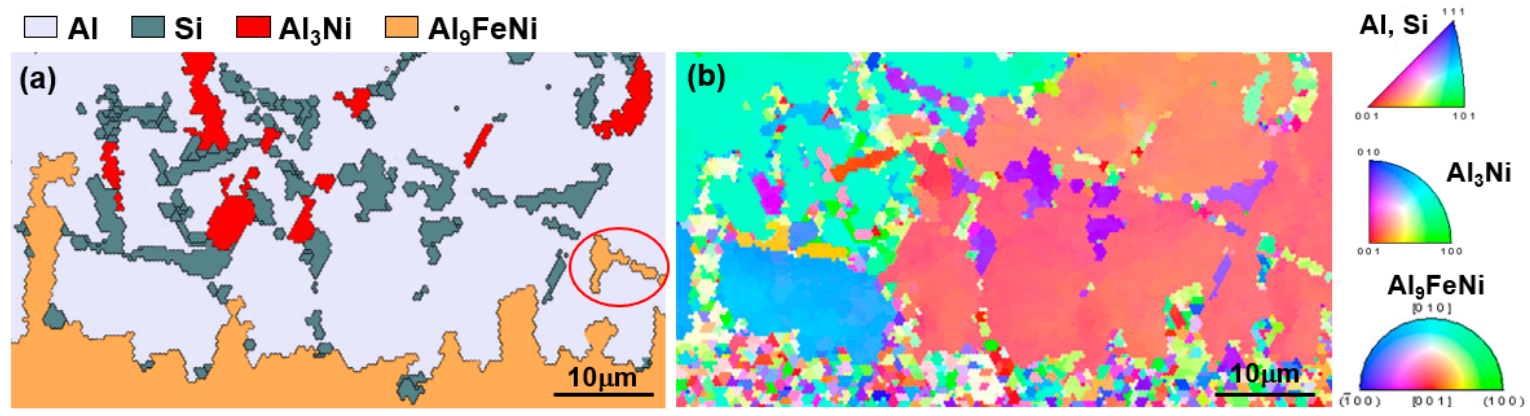

Figure 3. Electron backscatter diffraction (EBSD) analysis results using Chi-Scanning for the solidification layer (rectangular " $\mathrm{A}$ " in Figure 1): (a) Phase map and (b) inverse pole figure (IPF).

Table 2. Energy-dispersive X-ray spectroscopy (EDS) analysis results of phases denoted as 1-11 in Figure 2.

\begin{tabular}{|c|c|c|c|c|c|c|}
\hline No. & at $\% / w t \%$ & Al & $\mathbf{N i}$ & Si & $\mathrm{Fe}$ & Phase \\
\hline \multirow{2}{*}{1} & at $\%$ & 11.5 & - & 88.5 & - & \multirow{2}{*}{$\mathrm{Si}$} \\
\hline & $w t \%$ & 11.1 & - & 88.9 & - & \\
\hline \multirow{2}{*}{2} & at $\%$ & 5.3 & - & 94.7 & - & \multirow{2}{*}{$\mathrm{Si}$} \\
\hline & $w t \%$ & 5.1 & - & 94.9 & - & \\
\hline \multirow{2}{*}{3} & at $\%$ & 6.0 & - & 94.0 & - & \multirow{2}{*}{$\mathrm{Si}$} \\
\hline & $w t \%$ & 5.8 & - & 94.2 & - & \\
\hline \multirow{2}{*}{4} & at $\%$ & 82.5 & 15.9 & 1.1 & 0.5 & \multirow{2}{*}{$\mathrm{Al}_{3} \mathrm{Ni}$} \\
\hline & $w t \%$ & 69.2 & 28.9 & 0.9 & 1.0 & \\
\hline \multirow{2}{*}{5} & at $\%$ & 87.9 & 10.2 & 1.5 & 0.4 & \multirow{2}{*}{$\mathrm{Al}_{3} \mathrm{Ni}$} \\
\hline & $w t \%$ & 78.1 & 19.8 & 1.4 & 0.7 & \\
\hline \multirow{2}{*}{6} & at $\%$ & 84.4 & 12.8 & 2.1 & 0.7 & \multirow{2}{*}{$\mathrm{Al}_{3} \mathrm{Ni}$} \\
\hline & $w t \%$ & 72.8 & 24.1 & 1.9 & 1.2 & \\
\hline \multirow{2}{*}{7} & at $\%$ & 80.2 & 12.7 & 3.1 & 4.0 & \multirow{2}{*}{$\mathrm{Al}_{9} \mathrm{FeNi}(\mathrm{T})$} \\
\hline & $w t \%$ & 67.2 & 23.1 & 2.7 & 7.0 & \\
\hline \multirow{2}{*}{8} & at $\%$ & 81.5 & 13.0 & 1.0 & 4.5 & \multirow{2}{*}{$\mathrm{Al}_{9} \mathrm{FeNi}(\mathrm{T})$} \\
\hline & $w t \%$ & 67.8 & 23.5 & 0.9 & 7.8 & \\
\hline \multirow{2}{*}{9} & at $\%$ & 78.2 & 11.4 & 3.5 & 6.9 & \multirow{2}{*}{$\mathrm{Al}_{9} \mathrm{FeNi}(\mathrm{T})$} \\
\hline & $w t \%$ & 64.7 & 0.5 & 3.0 & 11.8 & \\
\hline \multirow{2}{*}{10} & at $\%$ & 80.1 & 10.3 & 2.1 & 7.5 & \multirow{2}{*}{$\mathrm{Al}_{9} \mathrm{FeNi}(\mathrm{T})$} \\
\hline & $w t \%$ & 66.7 & 18.5 & 1.8 & 13.0 & \\
\hline \multirow{2}{*}{11} & at $\%$ & 78.5 & 8.9 & 3.1 & 9.5 & \multirow{2}{*}{$\mathrm{Al}_{9} \mathrm{FeNi}(\mathrm{T})$} \\
\hline & $w t \%$ & 65.0 & 16.0 & 2.7 & 16.3 & \\
\hline
\end{tabular}

\subsubsection{Microstructural Evolution of Solidification Layer}

The formation of the Fe-containing phase in the solidification layer indicates that Fe was dissolved in the $\mathrm{Al}-7 \mathrm{wt} \% \mathrm{Ni}-6 \mathrm{wt} \% \mathrm{Si}$ liquid phase. Based on this, (Al-7wt\%Ni-6\%wtSi)-xFe pseudo-binary phase diagram was obtained using Thermo-Calc ${ }^{\mathrm{TM}}$ software, to evaluate the formation of a solidification layer under phase transformation during the cooling of the (Al-7wt $\% \mathrm{Ni}-6 \% \mathrm{wtSi})-\mathrm{xFe}$ liquid containing Fe.

Figure 4 presents the (Al-7wt $\% \mathrm{Ni}-6 \% \mathrm{wtSi})-\mathrm{xFe}$ pseudo-binary phase diagram obtained using Thermo-Calc ${ }^{\mathrm{TM}}$ software. In Figure 4 , it can be seen that the phases formed during cooling vary depending on the Fe content. The Fe content during solidification was $0.92 \mathrm{wt} \%$ (0.46 at $\%)$, as measured using EDS. The phase changes occurring during cooling proceeded in the order of primary $\mathrm{Al}_{3} \mathrm{Ni}$ + Liquid $\rightarrow \mathrm{Al}_{3} \mathrm{Ni}+\mathrm{Al}+$ Liquid $\rightarrow \mathrm{Al}_{3} \mathrm{Ni}+\tau_{1}+\mathrm{Al}+$ Liquid $\rightarrow \mathrm{Al}_{3} \mathrm{Ni}+\tau_{1}+\mathrm{Al}+\mathrm{Si}$. On the other hand, given the dimensions of the supercooled specimen (thickness of $1.4 \mathrm{~mm}$, width of $40 \mathrm{~mm}$, and length of $120 \mathrm{~mm}$ ), no phase transformation due to diffusion occurred at low temperatures. 
In particular, when $\mathrm{Al}_{3} \mathrm{Ni}$ and $\mathrm{Al}$ were preferentially formed at the initial stage of cooling, only $\mathrm{Si}$ was concentrated in the liquid; thus, $\mathrm{Si}$ was easily crystallized, and the $\tau_{1}\left(\mathrm{Al}_{2} \mathrm{Fe}_{3} \mathrm{Si}_{3}\right.$, triclinic) phase transformation degenerated. Hence, the solidification layer was considered to comprise $\mathrm{Al}_{3} \mathrm{Ni}+\mathrm{Al}+$ $\mathrm{Si}_{3}$ phases. On the other hand, in Figure 4, when Fe was concentrated to approximately $1.3-2.0 \mathrm{wt} \%$, the primary $\mathrm{T}$ phase could form during cooling, and even in the liquid. It was therefore considered that the solidification layer near the reaction layer contained a relatively high concentration of Fe; thus, an $\mathrm{Al}_{9} \mathrm{FeNi}(\mathrm{T})$ phase was generated.

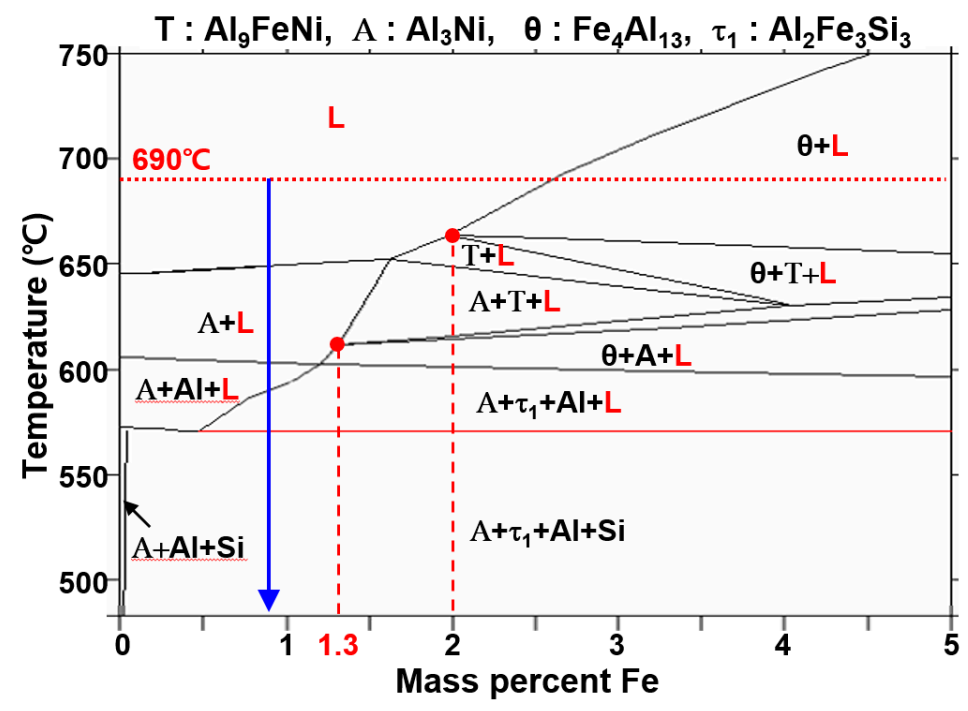

Figure 4. (Al-7Ni-6Si)-xFe (max. 5\%) pseudo-binary phase diagram calculated using Thermo-Calc ${ }^{\mathrm{TM}}$ software.

\subsection{Microstructure of Reaction Layer}

\subsubsection{Microstructural Identification of Reaction Layer}

Figure 5 presents an SEM image, in which the reaction layer region indicated by B in Figure 1 is enlarged. The reaction layer can be classified into three layers (R1, R2, R3) and one phase (white phases in the R3 layer). Table 3 presents the results of the EDS point analysis of the phases labeled 1-5. There was a decrease in the quantitative reliability, given that the phases were very fine. However, the expected phase in Table 3 was qualitatively predicted from the composition.

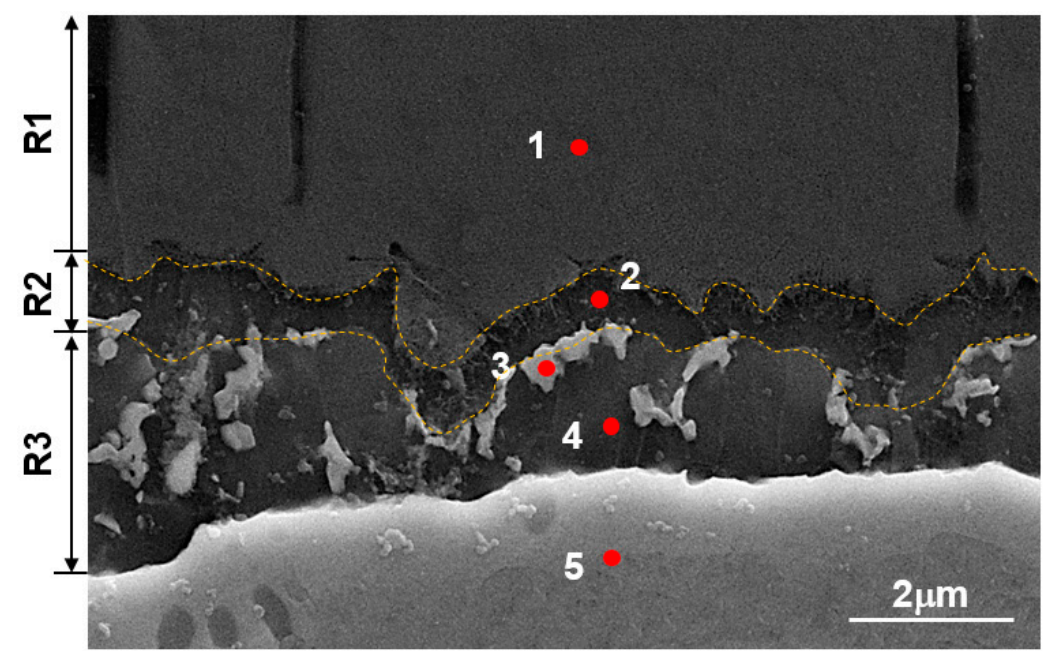

Figure 5. SEM image showing microstructure denoted as rectangular in Figure 1a and EDS analysis results of phases denoted as $1-5$. 
Table 3. EDS analysis results of phases denoted as 1-5 in Figure 5.

\begin{tabular}{|c|c|c|c|c|c|c|}
\hline No. & at $\% / w t \%$ & Al & $\mathbf{N i}$ & Si & $\mathbf{F e}$ & Phase \\
\hline \multirow{2}{*}{1} & at $\%$ & 79.0 & 14.3 & 0.6 & 6.1 & \multirow{2}{*}{$\mathrm{Al}_{9} \mathrm{FeNi}(\mathrm{T})$} \\
\hline & $\mathrm{wt} \%$ & 64.0 & 25.1 & 0.5 & 10.4 & \\
\hline \multirow[b]{2}{*}{2} & at $\%$ & 63.6 & 0.5 & 2.9 & 33.0 & \multirow{2}{*}{$\begin{array}{c}\mathrm{Fe}_{4} \mathrm{Al}_{13}(\theta) \text { or } \\
\mathrm{Fe}_{2} \mathrm{Al}_{5}(\eta)\end{array}$} \\
\hline & $w t \%$ & 46.8 & 0.7 & 2.2 & 50.3 & \\
\hline \multirow{2}{*}{3} & at $\%$ & 38.9 & - & 18.5 & 42.6 & \multirow{2}{*}{$\mathrm{Al}_{2} \mathrm{Fe}_{3} \mathrm{Si}_{3}\left(\tau_{1}\right)$} \\
\hline & $\mathrm{wt} \%$ & 26.5 & - & 13.2 & 60.3 & \\
\hline \multirow{2}{*}{4} & at $\%$ & 58.5 & 0.1 & 3.3 & 38.1 & \multirow{2}{*}{$\begin{array}{c}\mathrm{Fe}_{4} \mathrm{Al}_{13}(\theta) \text { or } \\
\mathrm{Fe}_{2} \mathrm{Al}_{5}(\eta)\end{array}$} \\
\hline & $w t \%$ & 41.5 & 0.1 & 2.5 & 55.9 & \\
\hline \multirow{2}{*}{5} & at $\%$ & 0.1 & 1.3 & 1.0 & 97.6 & \multirow{2}{*}{$\mathrm{Fe}$} \\
\hline & $w t \%$ & 0.2 & 1.2 & 2.0 & 96.6 & \\
\hline
\end{tabular}

To understand the composition, distribution, and grain size of the reaction layer, the TEM sample in Figure $1 b$ (reactive layer region) was evaluated using FIB and observed by scanning transmission electron microscopy (STEM). Figure 6a,b present the high-angle annular dark-field (HAADF) and bright-field images, respectively, and Figure $6 \mathrm{c}$ is an enlarged HAADF image denoted as X in Figure 6a. Moreover, Figure 7 presents the EDS mapping analysis of Al, Ni, Si and Fe. From the Figure 7, the sample was divided into several regions, with respect to the concentrations of $\mathrm{Al}, \mathrm{Ni}$, $\mathrm{Si}$ and $\mathrm{Fe}$. Table 4 presents the phase predictions from the EDS analysis of each area.

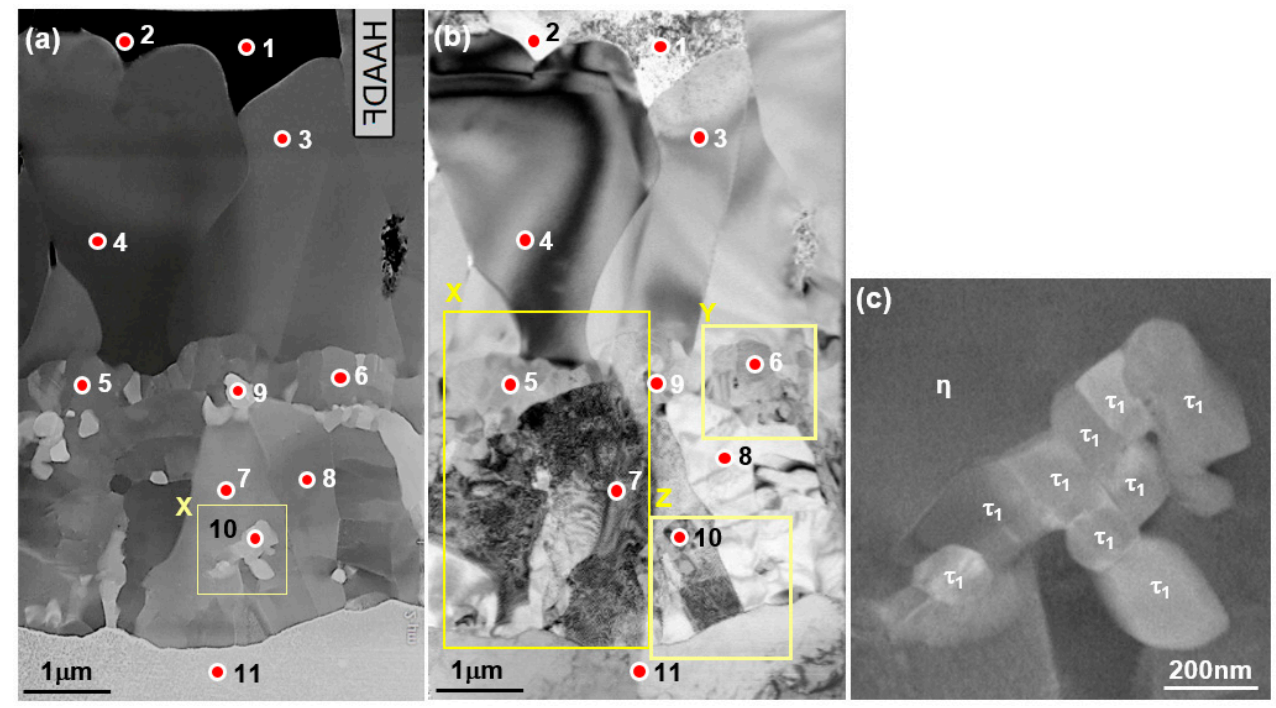

Figure 6. (a) HAADF image and (b) bright-field image of FE-TEM specimen for the area of reaction layer deflected by FIB; and (c) an enlarged image of the area indicated by $\mathrm{X}$ in Figure 6a.
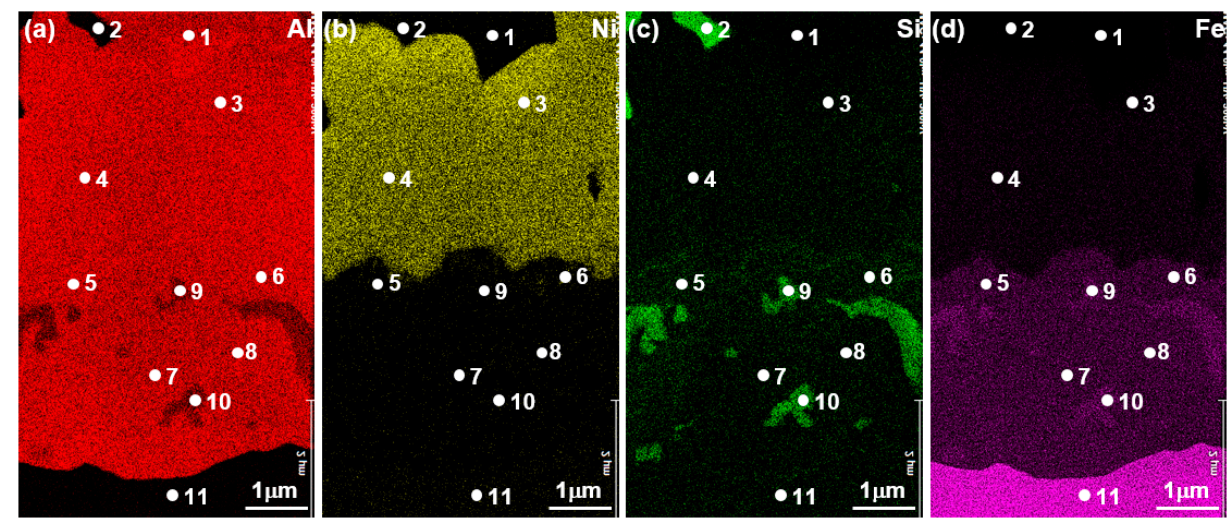

Figure 7. Results of EDS area-analysis of FE-TEM specimen: (a) $\mathrm{Al},(\mathbf{b}) \mathrm{Ni}$, (c) Si, and (d) Fe. 
Table 4. EDS analysis results of phases denoted as 1-11 in Figures 6 and 7.

\begin{tabular}{|c|c|c|c|c|c|c|}
\hline No. & at $\% / w t \%$ & Al & $\mathrm{Ni}$ & Si & $\mathbf{F e}$ & Phase \\
\hline \multirow[b]{2}{*}{1} & at $\%$ & 98.5 & 0.3 & 1.0 & 0.2 & \multirow{2}{*}{$\mathrm{Al}$} \\
\hline & $w t \%$ & 98.0 & 0.6 & 1.0 & 0.4 & \\
\hline \multirow[b]{2}{*}{2} & at $\%$ & 5.3 & 1.1 & 93.5 & 0.1 & \multirow{2}{*}{ Si } \\
\hline & $w t \%$ & 5.1 & 2.3 & 92.5 & 0.1 & \\
\hline \multirow{2}{*}{3} & at $\%$ & 79.7 & 11.6 & 1.7 & 7.0 & \multirow{2}{*}{$\mathrm{Al}_{9} \mathrm{FeNi}(\mathrm{T})$} \\
\hline & $w t \%$ & 65.8 & 20.9 & 1.4 & 11.9 & \\
\hline \multirow{2}{*}{4} & at $\%$ & 79.5 & 10.7 & 1.8 & 8.0 & \multirow{2}{*}{$\mathrm{Al}_{9} \mathrm{FeNi}(\mathrm{T})$} \\
\hline & $w t \%$ & 65.5 & 19.3 & 1.5 & 13.7 & \\
\hline \multirow{2}{*}{5} & at $\%$ & 73.1 & 0.1 & 3.6 & 23.2 & \multirow{2}{*}{$\mathrm{Fe}_{4} \mathrm{Al}_{13}(\theta)$} \\
\hline & $w t \%$ & 58.4 & 0.2 & 3.1 & 38.3 & \\
\hline \multirow{2}{*}{6} & at $\%$ & 72.2 & - & 4.1 & 23.7 & \multirow{2}{*}{$\mathrm{Fe}_{4} \mathrm{Al}_{13}(\theta)$} \\
\hline & $w t \%$ & 57.5 & - & 3.4 & 39.1 & \\
\hline \multirow{2}{*}{7} & at $\%$ & 71.6 & - & 2.6 & 25.8 & \multirow{2}{*}{$\mathrm{Fe}_{2} \mathrm{Al}_{5}(\eta)$} \\
\hline & $w t \%$ & 56.1 & - & 2.1 & 41.8 & \\
\hline \multirow{2}{*}{8} & at $\%$ & 71.8 & - & 1.7 & 26.5 & \multirow{2}{*}{$\mathrm{Fe}_{2} \mathrm{Al}_{5}(\eta)$} \\
\hline & $w t \%$ & 56.0 & - & 1.4 & 42.6 & \\
\hline \multirow{2}{*}{9} & at $\%$ & 32.6 & - & 31.7 & 35.7 & \multirow{2}{*}{$\mathrm{Al}_{2} \mathrm{Fe}_{3} \mathrm{Si}_{3}\left(\tau_{1}\right)$} \\
\hline & $w t \%$ & 23.4 & - & 23.6 & 53.0 & \\
\hline \multirow{2}{*}{10} & at $\%$ & 39.3 & - & 24.1 & 36.6 & \multirow{2}{*}{$\mathrm{Al}_{2} \mathrm{Fe}_{3} \mathrm{Si}_{3}\left(\tau_{1}\right)$} \\
\hline & $w t \%$ & 28.0 & - & 17.9 & 54.1 & \\
\hline \multirow{2}{*}{11} & at $\%$ & 0.7 & 0.6 & 0.8 & 97.9 & \multirow{2}{*}{$\mathrm{Fe}$} \\
\hline & $w t \%$ & 0.3 & 0.7 & 0.4 & 98.6 & \\
\hline
\end{tabular}

Figure 8 presents the diffraction pattern of the EDS point analysis region labeled 1-11 in Figure 6. Phases 1 and 2 represent $\mathrm{Al}$ and $\mathrm{Si}$, respectively, which were solidified layer structures. From the EDS point analysis, it was confirmed that phases 3 and 4 , which grew along the solidification layer, were the $\mathrm{Al}_{9} \mathrm{FeNi}\left(\mathrm{T}\right.$, monoclinic) phase. It can be seen that the $\mathrm{Al}_{9} \mathrm{FeNi}(\mathrm{T})$ phases had a relatively larger grain size than other phases, and the grain size on the side of the solidification layer was larger than that on the side of the base metal.

From the EDS point analysis, phases 5-8 consisted mainly of Al and Fe. Moreover, EDS mapping analysis revealed that the Fe concentration of phases 5 and 6 , which were in close proximity to the $T$ phases, was approximately 2 at $\%$ lower than that of phases 7 and 8 , which were in close proximity to the steel side, and the Si concentration was approximately 2 at\% higher. By diffraction pattern analysis, phases 5 and 6 were confirmed as a $\mathrm{Fe}_{4} \mathrm{Al}_{13}(\theta$, monoclinic) phase, and phases 7 and 8 were confirmed as a $\mathrm{Fe}_{2} \mathrm{Al}_{5}$ ( $\eta$, orthorhombic) phase. Furthermore, labeled 9 and 10 in Figure 6a which appears as a white particle, is identified as $\mathrm{Al}_{2} \mathrm{Fe}_{3} \mathrm{Si}_{3}$ ( $\tau_{1}$, triclinic) phase. Figure $6 \mathrm{c}$ reveals that the $\tau 1$ phases consist of several grains with diameters of 100-200 nm, rather than one grain.

Figure 9 presents a bright-field image, in which the $X-Z$ region of Figure $6 b$ is enlarged. Figure $9 a, b$ are the enlarged images of the $\mathrm{Al}{ }_{9} \mathrm{FeNi}(\mathrm{T})$ phase layer. It can be seen that the $\mathrm{Fe}_{4} \mathrm{Al}_{13}(\theta)$ phase layer formed to a thickness of less than $1 \mu \mathrm{m}$ directly under the $\mathrm{Al}_{9} \mathrm{FeNi}(\mathrm{T})$ phase layer. The grain diameter of the $\mathrm{Fe}_{4} \mathrm{Al}_{13}(\theta)$ phase adjacent to the $\mathrm{Al}_{9} \mathrm{FeNi}(\mathrm{T})$ phase layer was $100-500 \mathrm{~nm}$, and the grain diameter of the adjacent $\theta$ phase was approximately $200 \mathrm{~nm}$. Most of the $\mathrm{Fe}_{4} \mathrm{Al}_{13}(\theta)$ phase was characterized by a twin formation. Moreover, between the $\mathrm{Fe}_{4} \mathrm{Al}_{13}(\theta)$ phase layer and the steel, an $\mathrm{Fe}_{2} \mathrm{Al}_{5}(\eta)$ phase layer with a thickness of approximately $2.7 \mu \mathrm{m}$ was formed. The $\mathrm{Fe}_{2} \mathrm{Al}_{5}(\eta)$ phase grain had a columnar shape (aspect ratio: 1.5) and twin formations in several grains (Figure 8c). Figure 9d presents an HR-TEM image of the D region in Figure 9c. A Fe $3 \mathrm{AlC}(\kappa, \mathrm{FCC})$ layer was formed on the $\mathrm{Fe}_{2} \mathrm{Al}_{5}(\eta)$ phase layer/steel interface, with a thickness of approximately $10-15 \mathrm{~nm}$. 

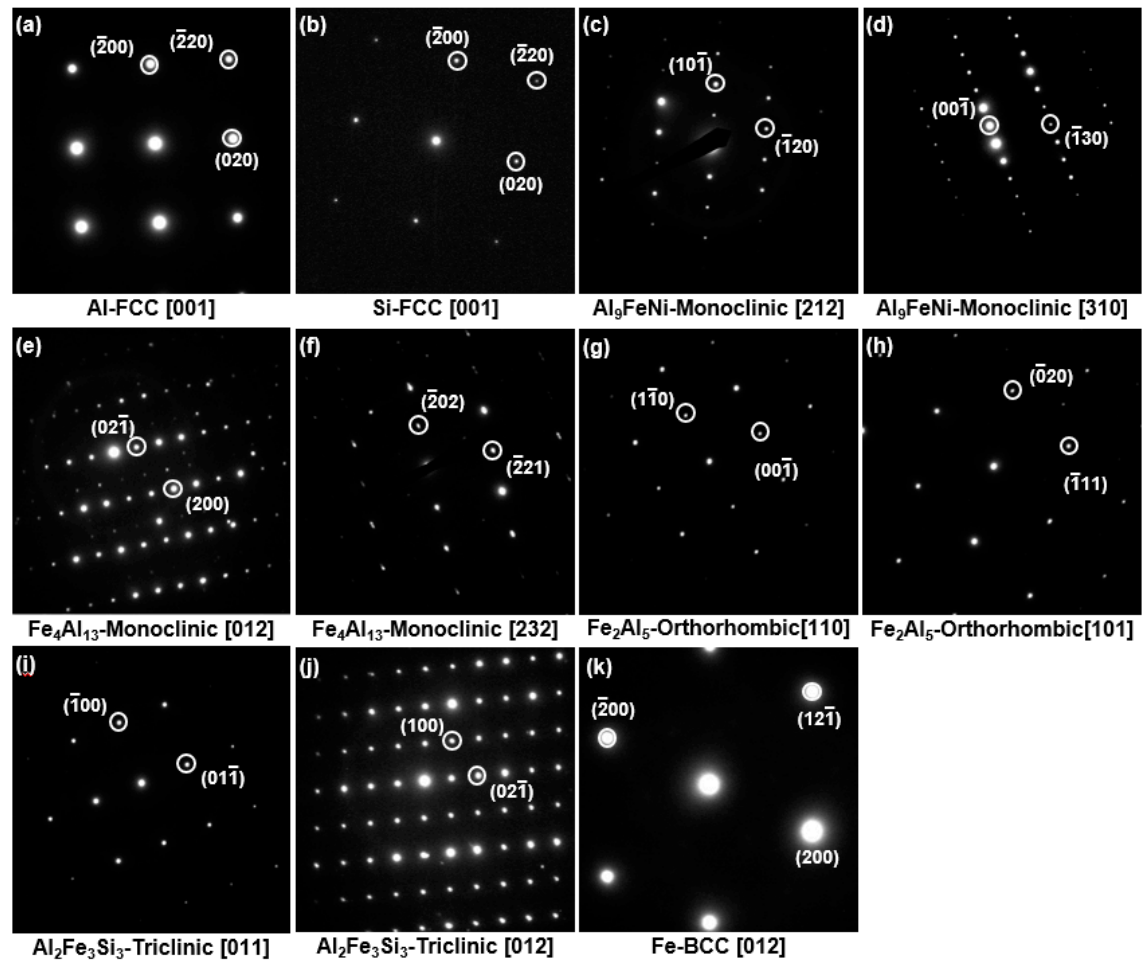

$\mathrm{Fe}_{4} \mathrm{Al}_{13}$-Monoclinic [232]
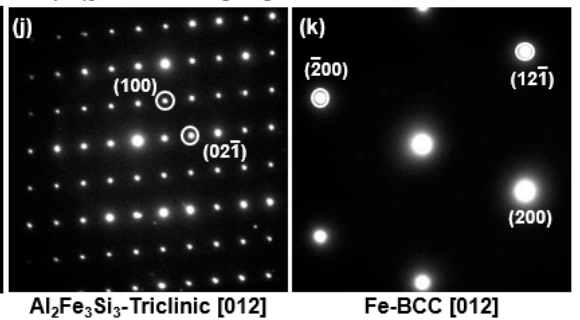

Figure 8. Diffraction patterns and those key diagram taking from area denoted as 1-11 in Figures 6 and 7, respectively. (a) $\mathrm{Al},(\mathbf{b}) \mathrm{Si},(\mathbf{c}, \mathbf{d}) \mathrm{Al}{ }_{9} \mathrm{FeNi}(\mathrm{T}),(\mathbf{e}, \mathbf{f}) \mathrm{Fe}_{4} \mathrm{Al}_{13}(\theta),(\mathbf{g}, \mathbf{h}) \mathrm{Fe}_{2} \mathrm{Al}_{5}(\eta),(\mathbf{i}, \mathbf{j}) \mathrm{Al}_{2} \mathrm{Fe}_{3} \mathrm{Si}_{3}\left(\tau_{1}\right)$, (k) Fe.
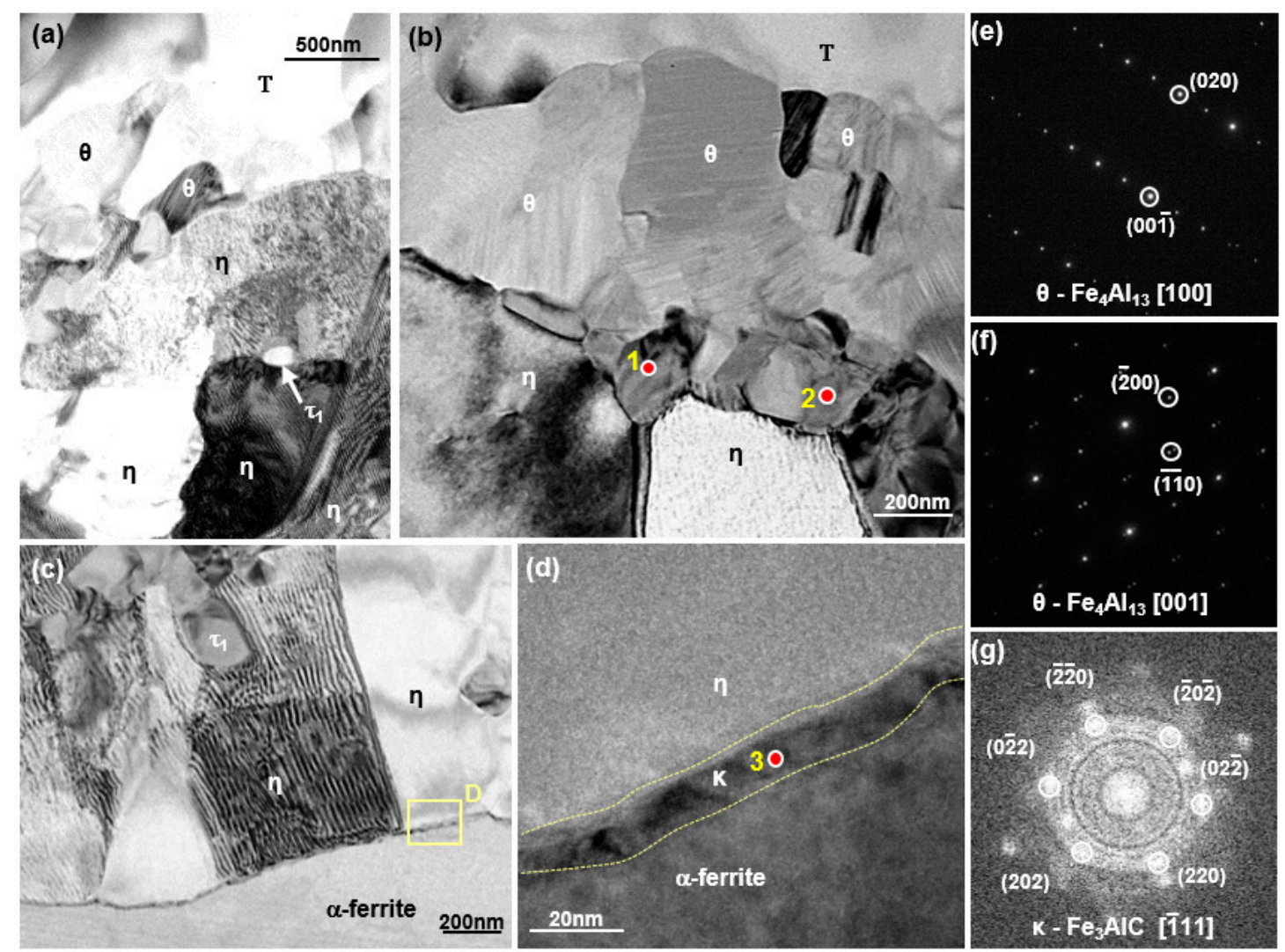

Figure 9. Bright-field images observed from rectangular area denoted as $X-Z$ in Figure 6b: (a) $X$ area, (b) Y area, (c) Z area, and (d) HR-TEM image observed from rectangular area denoted as D in (c) and (e-g) diffraction patterns and key diagram denoted as 1-3 in (b) and (d). 
Figure 10 presents the EBSD analysis results for the reaction layer. Figure 10a is the phase map, and Figure $10 \mathrm{~b}$ is the inverse pole figure (IPF). The reaction layer was formed in the order of the $\mathrm{T} / \theta / \eta$ layer on the solidification layer side. The very fine $\mathrm{Al}_{2} \mathrm{Fe}_{3} \mathrm{Si}_{3}\left(\tau_{1}\right)$ phase and $\mathrm{Fe}_{3} \mathrm{AlC}(\kappa)$ phases observed by TEM were not detected by EBSD, and were simply classified as $\mathrm{Fe}_{2} \mathrm{Al}_{5}(\eta)$ phase layers. This suggests that EBSD analysis cannot accurately determine the size and distribution of the phase when the thickness of the reaction layer is $1 \mu \mathrm{m}$ or less and the grain size is small.
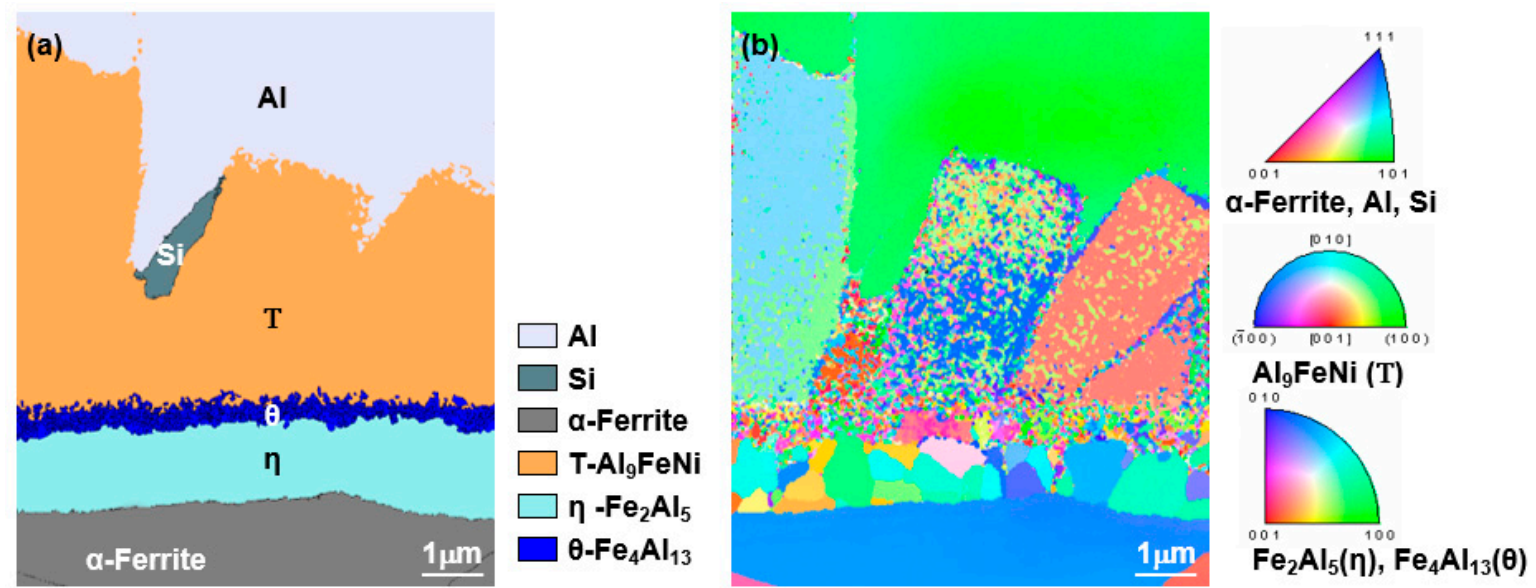

Figure 10. (a) Phase map and (b) IPF obtained from EBSD analysis using Chi-Scanning.

From the TEM observation and EBSD analysis results, it was confirmed that the reaction layer was formed in the order of $\mathrm{Al}_{9} \mathrm{FeNi}(\mathrm{T}) \rightarrow \mathrm{Fe}_{4} \mathrm{Al}_{13}(\theta) \rightarrow \mathrm{Fe}_{2} \mathrm{Al}_{5}(\eta)$ from the solidification side, and the $\mathrm{Al}_{2} \mathrm{Fe}_{3} \mathrm{Si}_{3}\left(\tau_{1}\right)$ phase was dispersed in the $\mathrm{Fe}_{2} \mathrm{Al}_{5}(\eta)$ phase layers. The characteristics of each phase are as follows. The $\mathrm{Al}_{9} \mathrm{FeNi}(\mathrm{T})$ phase had a monoclinic crystal structure, and the grains on the solidification layer side were larger than those on the base material side. The $\mathrm{Fe}_{4} \mathrm{Al}_{13}(\theta)$ phase had a monoclinic crystal structure, and the grain diameter was approximately 100-500 nm. In addition, twin formations were observed. The $\mathrm{Fe}_{2} \mathrm{Al}_{5}(\eta)$ phase had an orthorhombic crystal structure, and the grains developed in a columnar shape. Moreover, many $\mathrm{Fe}_{2} \mathrm{Al}_{5}(\eta)$ grains contained twin formations. $\mathrm{The} \mathrm{Al}_{2} \mathrm{Fe}_{3} \mathrm{Si}_{3}\left(\tau_{1}\right)$ phase contained a triclinic crystal structure, and several grains with diameters of 100-200 nm were present. The $\mathrm{Fe}_{3} \mathrm{AlC}(\mathrm{K})$ phase layer was formed with a thickness of approximately $10-15 \mathrm{~nm}$ at the $\mathrm{Fe}_{2} \mathrm{Al}_{5}(\eta)$ phase layer/steel interface.

\subsubsection{Microstructural Evolution of Reaction Layer}

Figure 11 presents a schematic diagram depicting the shape of the reaction phases and the reaction layer based on EBSD and TEM analyses of the plated layer. $\mathrm{Al}, \mathrm{Si}$, and $\mathrm{Al}_{3} \mathrm{Ni}$ were the major phases in the solidification layer, and a small $\mathrm{Al}_{9} \mathrm{FeNi}(\mathrm{T})$ phase was present near the reaction layer. The reaction layers were formed in the order of $\mathrm{Al}_{9} \mathrm{FeNi}(\mathrm{T}), \mathrm{Fe}_{4} \mathrm{Al}_{13}(\theta)$, and $\mathrm{Fe}_{2} \mathrm{Al}_{5}(\eta)$ from the solidification side, and the average thicknesses of the respective phases were $4.7 \mu \mathrm{m}, 500 \mathrm{~nm}$ and $2.0 \mu \mathrm{m}$. Moreover, $\mathrm{Al}_{2} \mathrm{Fe}_{3} \mathrm{Si}_{3}\left(\tau_{1}\right)$ was present in $\mathrm{Fe}_{2} \mathrm{Al}_{5}(\eta)$. Si was also formed between the $\mathrm{Al}_{9} \mathrm{FeNi}(\mathrm{T})$ phases, and the $\mathrm{Fe}_{3} \mathrm{AlC}(\kappa)$ layer was formed at the $\mathrm{Fe}_{2} \mathrm{Al}_{5}(\eta)$ layer/steel interface with a thickness of approximately $10-15 \mathrm{~nm}$. Fine twin formations were present in the $\mathrm{Fe}_{4} \mathrm{Al}_{13}(\theta)$ grains, and twin formations were present in several $\mathrm{Fe}_{2} \mathrm{Al}_{5}(\eta)$ grains. 


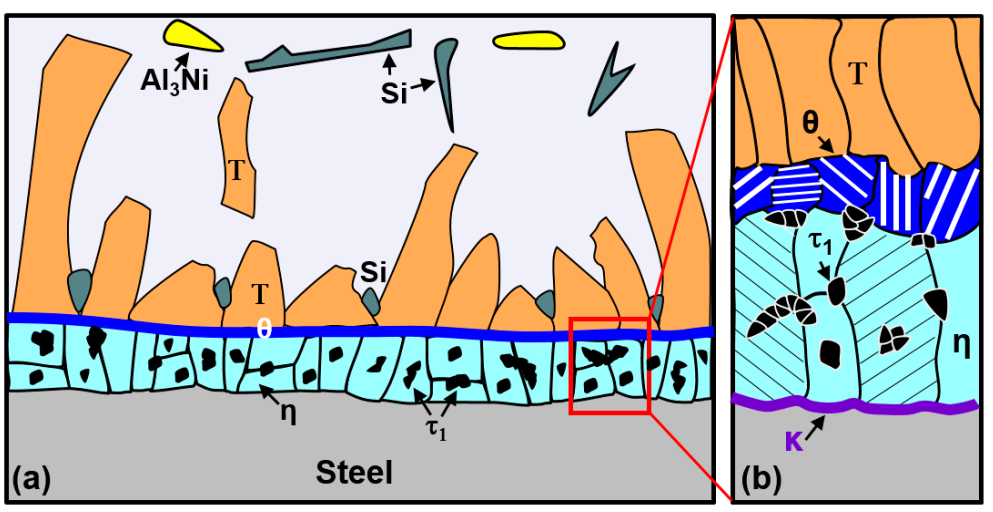

Figure 11. Schematic diagram of the distribution of phases in the solidification and reaction layers.

The microstructure of the $\mathrm{Al}-(5-10) \mathrm{wt} \% \mathrm{Si}$ alloy hot-dipped coating layer without $\mathrm{Ni}$ was compared with that of the coating layer in the study, as no previous studies were conducted on the Al-Ni-Si alloy hot-dipped coating. For the Al-(5-10)wt $\%$ Si hot-dipped steel, the reaction layer was formed in the order of $\mathrm{Al}_{7} \mathrm{Fe}_{2} \mathrm{Si}\left(\tau_{5}\right), \mathrm{Fe}_{4} \mathrm{Al}_{13}(\theta), \mathrm{Fe}_{2} \mathrm{Al}_{5}(\eta)$ [23,26,27] or $\mathrm{Al}_{7} \mathrm{Fe}_{2} \mathrm{Si}\left(\tau_{5}\right)$, and $\mathrm{Fe}_{2} \mathrm{Al}_{5}(\eta)$ [28] in the solidification layer. Moreover, it was reported that $\mathrm{Al}_{2} \mathrm{Fe}_{3} \mathrm{Si}_{3}\left(\tau_{1}\right)$ was formed within $\mathrm{Fe}_{2} \mathrm{Al}_{5}(\eta)$ in common. Therefore, when $\mathrm{Ni}$ was added to the Al-Si coating, $\mathrm{Al}_{9} \mathrm{FeNi}(\mathrm{T})$ was formed instead of $\mathrm{Al}_{7} \mathrm{Fe}_{2} \mathrm{Si}\left(\tau_{5}\right), \mathrm{Fe}_{4} \mathrm{Al}_{13}(\theta) / \mathrm{Fe}_{2} \mathrm{Al}_{5}(\eta)$ was formed in the lower layer, and $\mathrm{Al}_{2} \mathrm{Fe}_{3} \mathrm{Si}_{3}\left(\tau_{1}\right)$ was formed in $\mathrm{Fe}_{2} \mathrm{Al}_{5}(\eta)$.

From the phase diagram, the formation of the reaction layer in the order of $\mathrm{Al}_{9} \mathrm{FeNi}(\mathrm{T}), \mathrm{Fe}_{4} \mathrm{Al}_{13}(\theta)$, $\mathrm{Fe}_{2} \mathrm{Al}_{5}(\eta)$ in the solidification layer can be understood, in addition to the formation of $\mathrm{Al}_{2} \mathrm{Fe}_{3} \mathrm{Si}_{3}\left(\tau_{1}\right)$ in $\mathrm{Fe}_{2} \mathrm{Al}_{5}(\eta)$. Dipping the steel into a $690^{\circ} \mathrm{C} \mathrm{Al-7wt} \% \mathrm{Ni}-6 \mathrm{wt} \% \mathrm{Si}$ molten bath resulted in the partial dissolution of the steel. The reaction that occurred during hot-dipping at $690{ }^{\circ} \mathrm{C}$ was divided into two reactions: The reaction between the $\mathrm{Al}-7 \mathrm{wt} \% \mathrm{Ni}-6 \mathrm{wt} \% \mathrm{Si}$ melts and dissolved $\mathrm{Fe}$, and the diffusion reaction between the reaction layer formed in the previous reaction and steel. The influence of the increase in the Fe concentration on the phase formed in the Al-7wt\%Ni-6\%wtSi molten metal was therefore analyzed using a (Al-7wt $\% \mathrm{Ni}-6 \mathrm{wt} \% \mathrm{Si})$-xFe pseudo-binary phase diagram.

Figure 12 presents the (Al-7wt $\% \mathrm{Ni}-6 \mathrm{wt} \% \mathrm{Si}$ )-xFe pseudo-binary phase diagram obtained using Thermo-Calc ${ }^{\mathrm{TM}}$ software. Figure 12 reveals that solid $\mathrm{Fe}_{4} \mathrm{Al}_{13}(\theta)$ can be formed when Fe concentration of over $2.63 \mathrm{wt} \%$ is hot-dipped into the $\mathrm{Al}-7 \mathrm{wt} \% \mathrm{Ni}-6 \mathrm{wt} \% \mathrm{Si}$ molten metal at $690{ }^{\circ} \mathrm{C}$. When the $\mathrm{Fe}$ concentration was greater than $10.0 \mathrm{wt} \%, \mathrm{Fe}_{4} \mathrm{Al}_{13}(\theta)$ and $\mathrm{Al}_{9} \mathrm{FeNi}(\mathrm{T})$ can be formed, and when the Fe concentration was greater than $29.0 \mathrm{wt} \%$, three phases of $\mathrm{Fe}_{4} \mathrm{Al}_{13}(\theta), \mathrm{Al}_{3} \mathrm{Ni}$, and $\mathrm{Al}_{2} \mathrm{Fe}_{3} \mathrm{Si}_{3}\left(\tau_{1}\right)$ can be formed. In this study, $\mathrm{Al}_{3} \mathrm{Ni}$ was not formed in the reaction layer, and was only present in the solidification layer. Given that $\mathrm{Al}_{3} \mathrm{Ni}$ was not observed in the reaction layer, it was expected that the Fe concentration in the molten metal near the steel during coating was $29 \mathrm{wt} \%$ or lower. In addition, when the Fe concentration in the molten metal increased, $\theta$ first crystallized, and then $\mathrm{T}$ crystallized as the reaction progressed. This may be why the $\mathrm{T}$ layer was formed near the liquid phase, and the $\mathrm{Fe}_{4} \mathrm{Al}_{13}(\theta)$ layer was formed below the $\mathrm{Al}_{9} \mathrm{FeNi}(\mathrm{T})$ layer. 


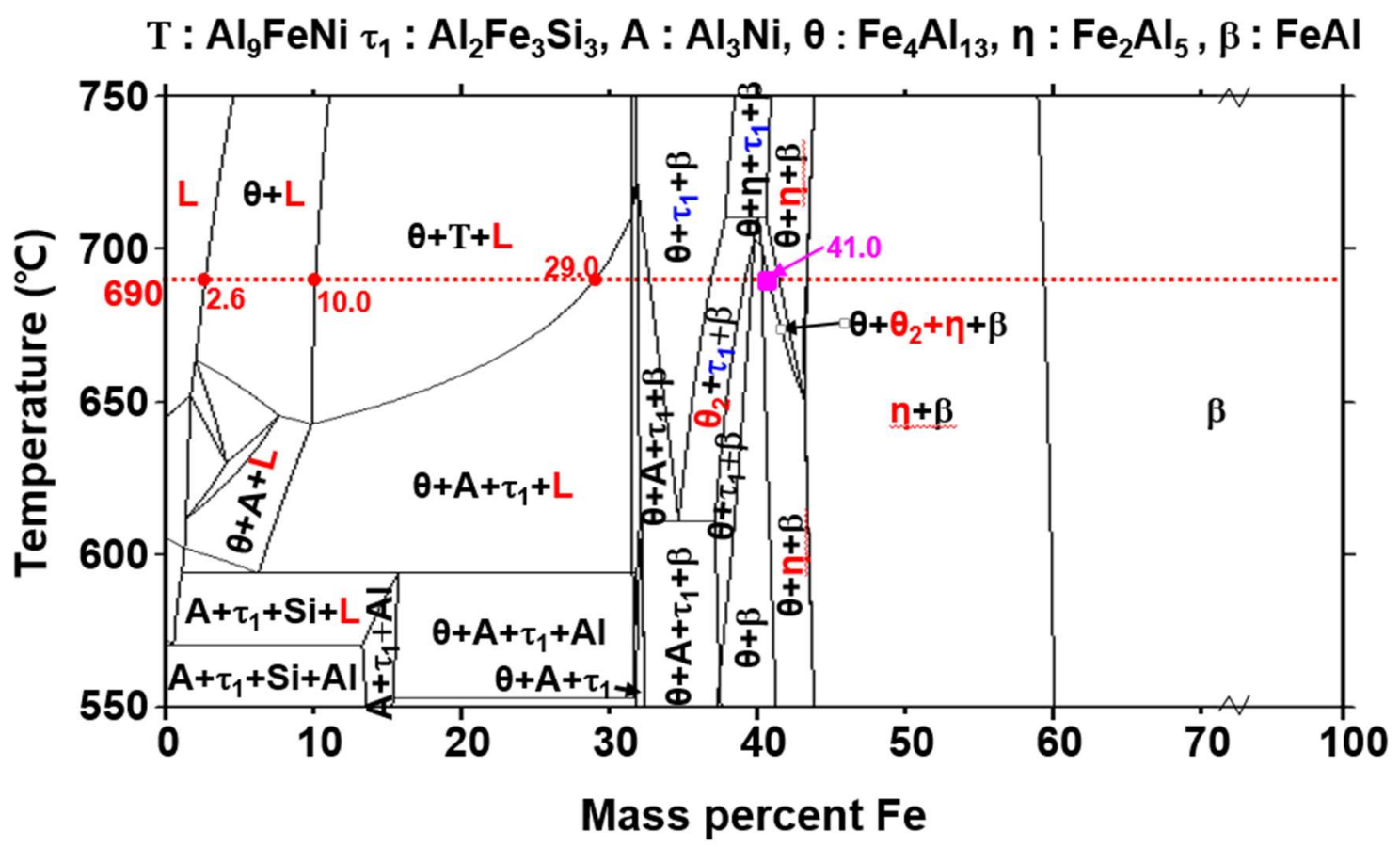

Figure 12. (Al-7wt $\% \mathrm{Ni}-6 w t \% \mathrm{Si})-x$ Fe pseudo-binary phase diagram obtained using Thermo-Calc ${ }^{\mathrm{TM}}$ software.

Table 5 presents the equilibrium phase composition at $690{ }^{\circ} \mathrm{C}$ in the $(\mathrm{Al}-7 \mathrm{wt} \% \mathrm{Ni}-6 \mathrm{wt} \% \mathrm{Si})-\mathrm{xFe}$ system obtained using Thermo-Calc ${ }^{\mathrm{TM}}$ software. With reference to Table 5, Si was not dissolved in $\mathrm{Al}_{9} \mathrm{FeNi}(\mathrm{T})$. During the formation and development of $\mathrm{Al}_{9} \mathrm{FeNi}(\mathrm{T})$ in the molten metal, $\mathrm{Si}$ phases were formed around $\mathrm{Al}_{9} \mathrm{FeNi}(\mathrm{T})$, due to the discharge and agglomeration of $\mathrm{Si}$ from $\mathrm{Al}_{9} \mathrm{FeNi}(\mathrm{T})$.

Table 5. Equilibrium concentration of phases at $690^{\circ} \mathrm{C}$ calculated using Thermo-Calc ${ }^{\mathrm{TM}}$ software.

\begin{tabular}{|c|c|c|c|c|c|}
\hline Phase at $690^{\circ} \mathrm{C}$ & at $\% / w t \%$ & $\mathrm{Al}$ & $\mathbf{N i}$ & Si & $\mathrm{Fe}$ \\
\hline \multirow{2}{*}{$\mathrm{T}-\mathrm{Al}_{9} \mathrm{FeNi}$} & at $\%$ & 81.9 & 7.6 & - & 10.5 \\
\hline & $\mathrm{wt} \%$ & 68.0 & 13.8 & - & 18.2 \\
\hline \multirow{2}{*}{$\theta_{1}-\mathrm{Fe}_{4} \mathrm{Al}_{13}$} & at $\%$ & 76.1 & 3.9 & - & 20.0 \\
\hline & $\mathrm{wt} \%$ & 60.4 & 6.7 & - & 32.9 \\
\hline \multirow{2}{*}{$\theta_{2}-\mathrm{Fe}_{4} \mathrm{Al}_{13}$} & at $\%$ & 73.3 & - & 3.3 & 23.4 \\
\hline & $\mathrm{wt} \%$ & 58.6 & - & 2.7 & 38.7 \\
\hline \multirow{2}{*}{$\eta-\mathrm{Fe}_{2} \mathrm{Al}_{5}$} & at $\%$ & 68.9 & 1.4 & 2.8 & 26.9 \\
\hline & $w t \%$ & 52.7 & 2.4 & 2.2 & 42.7 \\
\hline \multirow{2}{*}{$\beta-\mathrm{FeAl}$} & at $\%$ & 41.8 & 2.8 & 11.7 & 43.7 \\
\hline & $w t \%$ & 27.8 & 4.0 & 8.1 & 60.1 \\
\hline \multirow{2}{*}{$\tau_{1}-\mathrm{Al}_{2} \mathrm{Fe}_{3} \mathrm{Si}_{3}$} & at $\%$ & 63.1 & - & 14.7 & 22.2 \\
\hline & $w t \%$ & 50.8 & - & 12.2 & 37.0 \\
\hline
\end{tabular}

The formation mechanism of $\mathrm{Fe}_{2} \mathrm{Al}_{5}(\eta)$ was examined using the (Al-7wt $\left.\% \mathrm{Ni}-6 \mathrm{wt} \% \mathrm{Si}\right)-\mathrm{xFe}$ pseudo-binary phase diagram. Given that the Fe concentration at which the $\mathrm{Fe}_{2} \mathrm{Al}_{5}(\eta)$ was formed at $690{ }^{\circ} \mathrm{C}$ was approximately $41.0 \mathrm{wt} \%$ (as indicated by the pink rectangular in Figure 12), $\mathrm{Fe}_{2} \mathrm{Al}_{5}(\eta)$ could not be formed by dissolving $\mathrm{Fe}$ in the liquid phase during coating at $690{ }^{\circ} \mathrm{C}$. Another mechanism by which $\mathrm{Fe}_{2} \mathrm{Al}_{5}(\eta)$ could be formed as the solid phase diffusion reaction between the already formed reaction phase $\left(\mathrm{Fe}_{4} \mathrm{Al}_{13}(\theta), \mathrm{Al}_{9} \mathrm{FeNi}(\mathrm{T})\right)$ and steel. In particular, $\mathrm{Fe}_{2} \mathrm{Al}_{5}(\eta)$ can be formed through mutual diffusion when $\mathrm{Al}, \mathrm{Ni}$, and $\mathrm{Si}$ are diffused into the steel in the molten metal $\rightarrow \mathrm{Al}_{9} \mathrm{FeNi}(\mathrm{T}) \rightarrow \mathrm{Fe}_{4} \mathrm{Al}_{13}(\theta)$ path, and $\mathrm{Fe}$ is diffused through the reaction layer steel $\mathrm{Fe}_{4} \mathrm{Al}_{13}(\theta) \rightarrow \mathrm{Al}_{9} \mathrm{FeNi}(\mathrm{T}) \rightarrow$ molten metal path. There are three phases that can be formed on the steel side by mutual diffusion in the state diagram, namely, $\mathrm{FeAl}(\beta), \mathrm{Fe}_{2} \mathrm{Al}_{5}(\eta)$, and $\mathrm{Al}_{2} \mathrm{Fe}_{3} \mathrm{Si}_{3}\left(\tau_{1}\right)$. 
In this diffusion mechanism, the phase with the smallest concentration difference in comparison with $\mathrm{Fe}_{4} \mathrm{Al}_{13}(\theta)$ is easily formed. Therefore, $\mathrm{Fe}_{2} \mathrm{Al}_{5}(\eta)$ in Table 5 is most similar to $\mathrm{Fe}_{4} \mathrm{Al}_{13}(\theta)$ and $\mathrm{Al}$ and Fe concentrations. In Figure $9 \mathrm{~b}$, it can be seen that the grain size of $\mathrm{Fe}_{4} \mathrm{Al}_{13}(\theta)$ adjacent to $\mathrm{Fe}_{2} \mathrm{Al}_{5}(\eta)$ was significantly smaller than that of $\mathrm{Fe}_{4} \mathrm{Al}_{13}(\theta)$ adjacent to the $\mathrm{Al}_{9} \mathrm{FeNi}(\mathrm{T})$ layer. This is expected that the $\mathrm{Fe}_{4} \mathrm{Al}_{13}(\theta)$ grain decreased in size and disappeared, as it was transformed into $\mathrm{Fe}_{2} \mathrm{Al}_{5}(\eta)$ by the diffusion reaction.

The mechanism by which $\mathrm{Al}_{2} \mathrm{Fe}_{3} \mathrm{Si}_{3}\left(\tau_{1}\right)$ was produced within $\mathrm{Fe}_{2} \mathrm{Al}_{5}(\eta)$ is as follows. $\mathrm{Al}_{9} \mathrm{FeNi}(\mathrm{T})$ and $\mathrm{Fe}_{4} \mathrm{Al}_{13}(\theta)$ formed at Fe concentrations below $30 \mathrm{wt} \%$ did not dissolve $\mathrm{Si}$, as can be seen in Table 5 . Therefore, when $\mathrm{Al}_{9} \mathrm{FeNi}(\mathrm{T})$ and $\mathrm{Fe}_{4} \mathrm{Al}_{13}(\theta)$ discharged $\mathrm{Si}$ into the liquid phase, the Si phase was formed in the solidification layer. However, when $\mathrm{Si}$ was discharged toward the steel, $\mathrm{Al}_{2} \mathrm{Fe}_{3} \mathrm{Si}_{3}\left(\tau_{1}\right)$ phases that contained $\mathrm{Si}$ were precipitated. In Figures 6 and 7, the significant formation of $\mathrm{Al}_{2} \mathrm{Fe}_{3} \mathrm{Si}_{3}\left(\tau_{1}\right)$ phases at the $\mathrm{Fe}_{4} \mathrm{Al}_{13}(\theta) / \mathrm{Fe}_{2} \mathrm{Al}_{5}(\eta)$ interface can be explained by the formation mechanism of the $\mathrm{Al}_{2} \mathrm{Fe}_{3} \mathrm{Si}_{3}\left(\tau_{1}\right)$ phases.

Another reaction phase is the $\mathrm{Fe}_{3} \mathrm{AlC}(\mathrm{K})$ formed at the $\mathrm{Fe}_{2} \mathrm{Al}_{5}(\eta)$ / steel interface. Springer recently reported that an $800 \mathrm{~nm}$ band that consists of $\mathrm{FeAl}\left(\beta^{\prime}\right)$ and $\mathrm{Fe}_{3} \mathrm{AlC}(\kappa)$ phases was formed between the steel and $\mathrm{Fe}_{2} \mathrm{Al}_{5}(\eta)$ phase by inter-diffusion in the solid reaction of low-carbon steel and pure $\mathrm{Al}$ at $600{ }^{\circ} \mathrm{C}$; however, there was no mention of the formation mechanism [27]. In Figure 13, carbon was not detected in the $\mathrm{Al}_{9} \mathrm{FeNi}(\mathrm{T})$ and $\mathrm{Fe}_{2} \mathrm{Al}_{5}(\eta)$ layers. This confirms that the carbon solubility of $\mathrm{Al}{ }_{9} \mathrm{FeNi}(\mathrm{T})$ and $\mathrm{Fe}_{2} \mathrm{Al}_{5}(\eta)$ was very low. Given that the boron steel used in the study contained $0.22 \mathrm{wt} \%$ of carbon, it was suggested that the $\mathrm{Fe} 3 \mathrm{AlC}(\mathrm{K})$ layer was formed by carbon accumulation that discharged in the $\mathrm{Fe}_{2} \mathrm{Al}_{5}(\eta)$ region transformed from steel to $\mathrm{Fe}_{2} \mathrm{Al}_{5}(\eta)$. A study of pure $\mathrm{Al}$ [29] and the $\mathrm{Al}-7 \mathrm{Ni}$ [15] hot-dip coating on boron steels similarly reported the formation of a $\mathrm{Fe}_{3} \mathrm{AlC}(\mathrm{\kappa})$ layer at the grain boundaries of $\mathrm{Fe}_{2} \mathrm{Al}_{5}(\eta)$ and adjacent steels.
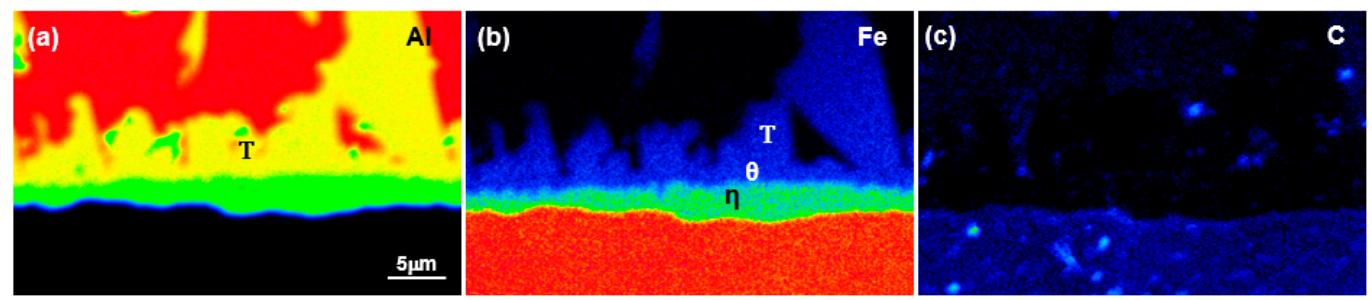

Figure 13. Electron probe micro-analysis (EPMA) area analysis near the reaction layer: (a) $\mathrm{Al}$, (b) $\mathrm{Fe}$, and (c) C.

During the formation of the reaction layer, It is expected that streaks occurred in the $\mathrm{Fe}_{4} \mathrm{Al}_{13}(\theta)$ and $\mathrm{Fe}_{2} \mathrm{Al}_{5}(\eta)$ phases, as can be seen in Figure $9 \mathrm{~b}$. Streaks in each $\theta$ and some $\eta$ grain are observed at regular intervals throughout the grain, not in only one specific part. And it also has a different orientation, like each grai's crystal orientation. Hence, streaks are expected to twin. Takata et al. reported that during the interfacial reaction between liquid-Al and solid-Fe, strain developed due to the volume expansion in the process of transformation from $\alpha$-ferrite to the $\eta$ phase, which resulted in the refinement of the $\eta$ phase in contact with the liquid phase [30]. In this study, it was considered that the twin formation in $\mathrm{Fe}_{4} \mathrm{Al}_{13}(\theta)$ and $\mathrm{Fe}_{2} \mathrm{Al}_{5}(\eta)$ between the $\mathrm{Al}_{9} \mathrm{FeNi}(\mathrm{T})$ and steel was caused by the strain generated by the lattice transformation $\left(\mathrm{Al}{ }_{9} \mathrm{FeNi}(\mathrm{T}) \rightarrow \mathrm{Fe}_{4} \mathrm{Al}_{13}(\theta), \mathrm{Fe}_{4} \mathrm{Al}_{13}(\theta) \rightarrow \mathrm{Fe}_{2} \mathrm{Al}_{5}(\eta)\right.$ ) that occurred in the layer interface. Moreover, $\mathrm{T}$ and $\theta$ have the same monoclinic structure, but their space group is different $\left(\mathrm{Al}_{9} \mathrm{FeNi}(\mathrm{T})\right.$ : P21/C [31], $\mathrm{Fe}_{4} \mathrm{Al}_{13}(\theta): \mathrm{C} 1 / \mathrm{m} 1$ (12) [32]). The twin formation can be attributed to the expansion caused by the $\mathrm{Al}_{9} \mathrm{FeNi}(\mathrm{T}) \rightarrow \mathrm{Fe}_{4} \mathrm{Al}_{13}(\theta)$ transformation.

\section{Conclusions}

The microstructures of the reaction layer and phases formed on boron steel hot-dipped in Al-7wt\%Ni-6wt\%Si were investigated using FIB, TEM, and EBSD. The formation mechanism of 
each phase was examined by employing a (Al-7wt $\% \mathrm{Ni}-6 \mathrm{wt} \% \mathrm{Si})$-xFe pseudo-binary phase diagram obtained using Thermo-Calc ${ }^{\mathrm{TM}}$ software. The results are as follows.

(1) The solidification layer consisted mainly of $\mathrm{Al}, \mathrm{Al}_{3} \mathrm{Ni}$, and $\mathrm{Si}$ phases, and a small $\mathrm{Al}_{9} \mathrm{FeNi}(\mathrm{T})$ phase was observed near the reaction layer. By analyzing the solidification process using a phase diagram, it was found that three phases $\left(\mathrm{Al}, \mathrm{Al}_{3} \mathrm{Ni}\right.$ and $\mathrm{Si}$ ) were formed in the low Fe concentration region ( $0.92 \mathrm{wt} \%$ of $\mathrm{Fe}$ ). Moreover, a $\mathrm{T}$ phase was formed during cooling in the high Fe concentration region (1.3 $\mathrm{wt} \%$ of Fe or higher).

(2) The reaction layers were formed in the order of $\mathrm{Al}_{9} \mathrm{FeNi}(\mathrm{T}), \mathrm{Fe}_{4} \mathrm{Al}_{13}(\theta)$, and $\mathrm{Fe}_{2} \mathrm{Al}_{5}(\eta)$ from the solidification side, and the average thicknesses of the phases were $4.7 \mu \mathrm{m}, 500 \mathrm{~nm}$ and $2.0 \mu \mathrm{m}$, respectively. Moreover, $\mathrm{Si}$ was formed around the $\mathrm{T}$ phase, and the $\mathrm{Fe}_{3} \mathrm{AlC}(\mathrm{K})$ layer was formed at the $\mathrm{Fe}_{2} \mathrm{Al}_{5}(\eta)$ layer/steel interface with a thickness of approximately $10-15 \mathrm{~nm}$.

(3) The $\mathrm{Al}{ }_{9} \mathrm{FeNi}(\mathrm{T})$ phase possessed a monoclinic crystal structure (space group: $\mathrm{P} 21 / \mathrm{C}$ ), and the grains on the side of the solidification layer were larger than those on the side of the base metal. The $\mathrm{Fe}_{4} \mathrm{Al}_{13}(\theta)$ phase possessed a monoclinic crystal structure (space group: $\mathrm{C} 1 / \mathrm{m} 1(12)$ ), the grain diameter was approximately $100-500 \mathrm{~nm}$, and twin formations were present. By analyzing the formation mechanisms using the (Al-7wt $\% \mathrm{Ni}-6 \mathrm{wt} \% \mathrm{Si})-\mathrm{xFe}$ pseudo-binary phase diagram, it was confirmed that $\mathrm{Fe}_{4} \mathrm{Al}_{13}(\theta)$ was formed by the dissolution reaction of $\mathrm{Fe}$ in the liquid phase. Moreover, $\mathrm{Fe}_{4} \mathrm{Al}_{13}(\theta)$ can be formed when the Fe concentration exceeds 2.63 $\mathrm{wt} \%$ in the $690{ }^{\circ} \mathrm{C} \mathrm{Al-7wt} \% \mathrm{Ni}-6 \mathrm{wt} \% \mathrm{Si}$ molten metal. When the concentration of Fe increased to $10.0-29.0 \mathrm{wt} \%$, isothermal solidification occurred in the $\mathrm{Fe}_{4} \mathrm{Al}_{13}(\theta)$ and $\mathrm{Al}_{9} \mathrm{FeNi}(\mathrm{T})$ phases simultaneously. Moreover, given that the $\mathrm{T}$ phase did not dissolve $\mathrm{Si}$, it was discharged, and the Si phase was formed around the $\mathrm{T}$ phase.

(4) $\mathrm{Fe}_{2} \mathrm{Al}_{5}(\eta)$ was interpreted from the phase diagram as being formed by a diffusion reaction between $\mathrm{Fe}_{4} \mathrm{Al}_{13}(\theta)$ and steel, not a dissolution reaction. Given that the difference in the compositions of $\mathrm{Fe}_{4} \mathrm{Al}_{13}(\theta)$ and $\mathrm{Fe}_{2} \mathrm{Al}_{5}(\eta)$ was the smallest, $\mathrm{Fe}_{4} \mathrm{Al}_{13}(\theta)$ was transformed into $\mathrm{Fe}_{2} \mathrm{Al}_{5}(\eta)$ by mutual diffusion. This was confirmed by the grain size of $\mathrm{Fe}_{4} \mathrm{Al}_{13}(\theta)$ adjacent to $\mathrm{Fe}_{2} \mathrm{Al}_{5}(\eta)$, which was significantly smaller than that of $\mathrm{Fe}_{4} \mathrm{Al}_{13}(\theta)$ adjacent to $\mathrm{Al}_{9} \mathrm{FeNi}(\mathrm{T})$. Moreover, given that $\mathrm{Fe}_{4} \mathrm{Al}_{13}(\theta)$ does not exhibit $\mathrm{Si}$ solubility, $\mathrm{Si}$ was discharged into $\mathrm{Fe}_{2} \mathrm{Al}_{5}(\eta)$ or steel. Hence, $\mathrm{Al}_{2} \mathrm{Fe}_{3} \mathrm{Si}_{3}\left(\tau_{1}\right)$, which contained a large amount of $\mathrm{Si}$, was precipitated. This is consistent with the formation of $\mathrm{Al}_{2} \mathrm{Fe}_{3} \mathrm{Si}_{3}\left(\tau_{1}\right)$, especially at the $\mathrm{Fe}_{4} \mathrm{Al}_{13}(\theta) / \mathrm{Fe}_{2} \mathrm{Al}_{5}(\eta)$ interface.

(5) $\mathrm{The}_{\mathrm{Fe}} \mathrm{AlC}(\mathrm{K})$ layer was formed by carbon accumulation that discharged in the $\mathrm{Fe}_{2} \mathrm{Al}_{5}(\eta)$ region transformed from steel to $\mathrm{Fe}_{2} \mathrm{Al}_{5}(\eta)$.

(6) The twin formations in the $\mathrm{Fe}_{4} \mathrm{Al}_{13}(\theta)$ and $\mathrm{Fe}_{2} \mathrm{Al}_{5}(\eta)$ grains were due to strains caused by the lattice transformation $\left(\mathrm{Al}{ }_{9} \mathrm{FeNi}(\mathrm{T}) \rightarrow \mathrm{Fe}_{4} \mathrm{Al}_{13}(\theta), \mathrm{Fe}_{4} \mathrm{Al}_{13}(\theta) \rightarrow \mathrm{Fe}_{2} \mathrm{Al}_{5}(\eta)\right)$ in the constrained state, wherein these phases were present between the $\mathrm{Al}_{9} \mathrm{FeNi}(\mathrm{T})$ layer and steel.

Author Contributions: J.-Y.L., H.H., N.K. and C.-Y.K. conceived and designed the experiments; J.-Y.L. and H.H. performed the experiments; N.K. and J.-Y.L. analyzed the data; and J.-Y.L. and C.-Y.K. wrote the paper.

Funding: This work was supported by the National Research Foundation of Korea (NRF) grant funded by the Korean government (MSIP) through the Engineering Research Center (No. 2012R1A5A1048294).

Conflicts of Interest: The authors declare no conflict of interest. The funding sponsors had no role in the design of the study; the collection, analyses, or interpretation of data; the writing of the manuscript, or in the decision to publish the results.

\section{References}

1. Aranda, L.G.; Ravier, P.; Chastel, Y. Hot Stamping of Quenchable Steels: Material Data and Process Simulations. In Proceedings of the IDDRG, Bled, Slovenia, 11-14 May 2003; pp. 164-166.

2. Vaissiere, L.; Laurent, J.; Reinhardt, A. Development of Pre-Coated Boron Steel for Applications on psa Peugeot Citroen and Renault Bodies in White. SAE Tech. Pap. 2002. [CrossRef] 
3. Mega, T.; Hasegawa, K.; Kawabe, H. Ultra high-strength steel sheets for bodies, reinforcement parts, and seat frame parts of automobile-Ultra high-strength steel sheets leading to great improvement in crash-worthiness. JFE Tech. Rep. 2004, 4, 38-43.

4. Kolleck, R.; Veit, R.; Merklein, M.; Lechler, J.; Geiger, M. Investigation on induction heating for hot stamping of boron alloyed steels. CIRP Ann. 2009, 58, 275-278. [CrossRef]

5. Liu, H.; Xing, Z.; Bao, J.; Song, B. Investigation of the hot-stamping process for advanced high-strength steel sheet by numerical simulation. J. Mater. Eng. Perform. 2010, 19, 325-334. [CrossRef]

6. Kobayashi, S.; Yakou, T. Control of intermetallic compound layers at interface between steel and aluminum by diffusion-treatment. Mater. Sci. Eng. A 2002, 338, 44-53. [CrossRef]

7. Chang, Y.-Y.; Tsaur, C.-C.; Rock, J.C. Microstructure studies of an aluminide coating on 9Cr-1Mo steel during high temperature oxidation. Surf. Coat. Technol. 2006, 200, 6588-6593. [CrossRef]

8. Wang, C.-J.; Chen, S.-M. The high-temperature oxidation behavior of hot-dipping Al-Si coating on low carbon steel. Surf. Coat. Technol. 2006, 200, 6601-6605. [CrossRef]

9. Jarnverk Ab, N. Manufacturing of a hardened steel article. UK Patent GB1490535, 2 November 1977.

10. Ehling, W.; Cretteur, L.; Pic, A.; Vierstraete, R.; Yin, Q. Development of a Laser Decoating Process for Fully Functional al-si Coated Press Hardened Steel Laser Welded Blank Solutions. In Proceedings of the 5th International WLT-Conference on Lasers in Manufacturing 2009, Munich, Germany, 15-18 June 2009; p. 6.

11. Jung, B.-H.; Kong, J.-P.; Kang, C.-Y. Effect of hot-stamping heat treatment on microstructure and hardness in TWB laser joints of Al-Si-coated boron steel and Zn-coated DP steel. Korean J. Metals Mater. 2012, 50, $224-232$.

12. Oh, M.-H.; Kong, J.-P.; Kwon, M.-S.; Kang, C.-Y. Effect of hot-stamping on microstructures and tensile properties of Al-Si coated boron steel welds with laser source. J. Weld. Join. 2013, 31, 96-106. [CrossRef]

13. Yoon, T.-J.; Oh, M.-H.; Shin, H.-J.; Kang, C.-Y. Comparison of microstructure and phase transformation of laser-welded joints in Al-10wt\% Si-coated boron steel before and after hot stamping. Mater. Charact. 2017, 128, 195-202. [CrossRef]

14. Kwak, S.-Y.; Yun, J.-G.; Lee, J.-H.; Shin, D.-I.; Kang, C.-Y. Identification of intermetallic compounds and its formation mechanism in boron steel hot-dipped in Al-7 wt.\% Mn alloy. Coatings 2017, 7, 222. [CrossRef]

15. Lee, J.-H.; Yun, J.-G.; Kwak, S.-Y.; Kang, C.-Y. Nucleation and growth of intermetallic compounds formed in boron steel hot-dipped in Al-Ni alloy. Coatings 2017, 7, 195. [CrossRef]

16. Eggeler, G.; Auer, W.; Kaesche, H. On the influence of silicon on the growth of the alloy layer during hot dip aluminizing. J. Mater. Sci. 1986, 21, 3348-3350. [CrossRef]

17. Akdeniz, M.V.; Mekhrabov, A.O.; Yilmaz, T. The role of si addition on the interfacial interaction in Fe-Al diffusion layer. Scr. Metall. Mater. 1994, 31, 1723-1728. [CrossRef]

18. Shady, M.; El-Sissi, A.; Attia, A.; El-Mahallawy, N.; Taha, M.; Reif, W. On the technological properties of steel strips aluminized in Al-Si baths. J. Mater. Sci. Lett. 1996, 15, 1032-1036. [CrossRef]

19. Heumann, T.; Dittrich, S. Uber die kinetik der reaktion von festem und flûssigem aluminium mit eisen. $Z$. Metall. 1959, 50, 617-625.

20. Lemmens, B.; Springer, H.; Duarte, M.J.; De Graeve, I.; De Strycker, J.; Raabe, D.; Verbeken, K. Atom probe tomography of intermetallic phases and interfaces formed in dissimilar joining between $\mathrm{Al}$ alloys and steel. Mater. Charact. 2016, 120, 268-272. [CrossRef]

21. Shankar, S.; Apelian, D. Die soldering: Mechanism of the interface reaction between molten aluminum alloy and tool steel. Metall. Mater. Trans. B 2002, 33, 465-476. [CrossRef]

22. Zhang, K.; Bian, X.; Li, Y.; Liu, Y.; Yang, C. New evidence for the formation and growth mechanism of the intermetallic phase formed at the Al/Fe interface. J. Mater. Res. 2013, 28, 3279-3287. [CrossRef]

23. Lemmens, B.; Springer, H.; De Graeve, I.; De Strycker, J.; Raabe, D.; Verbeken, K. Effect of silicon on the microstructure and growth kinetics of intermetallic phases formed during hot-dip aluminizing of ferritic steel. Surf. Coat. Technol. 2017, 104-109. [CrossRef]

24. Yun, J.-G.; Lee, J.-H.; Kwak, S.-Y.; Kang, C.-Y. Study on the formation of reaction phase to Si addition in boron steel hot-dipped in Al-7Ni alloy. Coatings 2017, 7, 186. [CrossRef]

25. Handbook, A. Alloy phase diagrams. ASM Int. 1992, 3, 2-319.

26. Cheng, W.-J.; Wang, C.-J. Microstructural evolution of intermetallic layer in hot-dipped aluminide mild steel with silicon addition. Surf. Coat. Technol. 2011, 205, 4726-4731. [CrossRef] 
27. Springer, H.; Kostka, A.; Payton, E.; Raabe, D.; Kaysser-Pyzalla, A.; Eggeler, G. On the formation and growth of intermetallic phases during interdiffusion between low-carbon steel and aluminum alloys. Acta Mater. 2011, 59, 1586-1600. [CrossRef]

28. Gui, Z.-X.; Liang, W.-K.; Liu, Y.; Zhang, Y.-S. Thermo-mechanical behavior of the Al-Si alloy coated hot stamping boron steel. Mater. Des. 2014, 60, 26-33. [CrossRef]

29. Shin, D.; Lee, J.-Y.; Heo, H.; Kang, C.-Y. Formation procedure of reaction phases in Al hot dipping process of steel. Metals 2018, 8, 820. [CrossRef]

30. Takata, N.; Nishimoto, M.; Kobayashi, S.; Takeyama, M. Crystallography of Fe2Al5 phase at the interface between solid Fe and liquid Al. Intermetallics 2015, 67, 1-11. [CrossRef]

31. Pearson, W.B. A handbook of Lattice Spacings and Structures of Metals and Alloys-2; Pergamon: London, UK, 1967.

32. Black, P. The structure of FeAl3. II. Acta Crystallogr. 1955, 8, 175-182. [CrossRef]

(C) 2018 by the authors. Licensee MDPI, Basel, Switzerland. This article is an open access article distributed under the terms and conditions of the Creative Commons Attribution (CC BY) license (http://creativecommons.org/licenses/by/4.0/). 